\title{
Economic Uncertainty and Earnings Management
}

\section{Citation}

Stein, Luke C.D., and Charles C.Y. Wang. "Economic Uncertainty and Earnings Management." Harvard Business School Working Paper, No. 16-103, March 2016.

\section{Permanent link}

http://nrs.harvard.edu/urn-3:HUL.InstRepos:26274753

\section{Terms of Use}

This article was downloaded from Harvard University's DASH repository, and is made available under the terms and conditions applicable to Open Access Policy Articles, as set forth at http:// nrs.harvard.edu/urn-3:HUL.InstRepos:dash.current.terms-of-use\#OAP

\section{Share Your Story}

The Harvard community has made this article openly available.

Please share how this access benefits you. Submit a story.

Accessibility 


\section{Economic Uncertainty and Earnings Management}

Luke C.D. Stein

Charles C.Y. Wang

Working Paper 16-103 


\title{
Economic Uncertainty and Earnings Management
}

\author{
Luke C.D. Stein
}

Arizona State University

Charles C.Y. Wang

Harvard Business School

Working Paper 16-103 


\title{
Economic Uncertainty and Earnings Management
}

\author{
Luke C.D. Stein \\ W. P. Carey School of Business \\ Arizona State University \\ Charles C.Y. Wang* \\ Harvard Business School
}

March $2016^{\dagger}$

\begin{abstract}
In the presence of managerial short-termism and asymmetric information about skill and effort provision, firms may opportunistically shift earnings from uncertain to more certain times. We document that firms report more negative discretionary accruals when financial markets are less certain about their future prospects. Stock-price responses to earnings surprises are moderated when firm-level uncertainty is high, consistent with performance being attributed more to luck rather than skill and effort, which can create incentives to shift earnings toward lower-uncertainty periods. We show that the resulting opportunistic earnings management is concentrated in CEOs, firms, and periods where such incentives are likely to be strongest: (1) where CEO wealth is sensitive to change in the share price, (2) where announced earnings are particularly likely to be an important source of information about managerial ability and effort, and (3) before implementation of Sarbanes-Oxley made opportunistic earnings management more challenging. Our evidence highlights a novel channel through which uncertainty affects managerial decision making in the presence of agency conflicts.
\end{abstract}

JEL: G34, J33, M41, M52

Keywords: Earnings management, discretionary accruals, uncertainty, implied volatility, earnings response coefficient

*Stein is an assistant professor of finance at Arizona State University's W. P. Carey School of Business, and can be reached at luke.stein@asu.edu. Wang is an assistant professor of business administration at Harvard Business School, and can be reached at charles.cy.wang@hbs.edu. We thank Selina Jan, Kyle Thomas, and particularly Hong Zhao for invaluable research assistance. For helpful comments, we thank Hank Bessembinder, Nicholas Bloom, Akash Chattopadhyay, Paul Healy, Laura Lindsey, Iván Marinovic, Eugene Soltes, Vicki Tang (discussant), Stephen Terry, and seminar participants at Hong Kong Polytechnic University, the University of Hong Kong, the 2015 Chinese Accounting Academic Conference, the 2015 MIT Asia Conference in Accounting, and the 2015 Econometric Society World Congress.

†This draft updated March 23, 2016. 


\section{Introduction}

Uncertainty has a crucial impact on economic outcomes. A growing literature examines how uncertainty affects aggregate economic growth (e.g., Baker and Bloom, 2013), business cycles (e.g., Bloom et al., 2011; Basu and Bundick, 2012; Bidder and Smith, 2012; Christiano et al., 2013; Bianchi et al., 2014), investment dynamics (e.g., Bachmann and Bayer, 2014), and equity prices and risk premia (e.g., Pastor and Veronesi, 2012). Complementing these studies, a number of papers examine how economic uncertainty impacts aspects of managerial decision making, such as investment, R\&D spending, hiring, and advertising (e.g., Pindyck, 1993; Dixit and Pindyck, 1994; Bloom, 2009; Julio and Yook, 2012; Stein and Stone, 2014; Arif et al., 2015; Gulen and Ion, 2016). In particular, the evidence suggests that uncertainty can amplify business cycles by affecting decisions in firms.

This paper examines how economic uncertainty impacts an important dimension of managerial decision making: the reporting and management of accounting earnings. Top executives devote considerable attention to earnings and their management (Graham et al., 2005), and a large body of literature in accounting and finance has investigated various contexts in which earnings are managed to meet management objectives around various corporate events. ${ }^{1}$

When managers' and shareholders' incentives diverge, and when there is information asymmetry between the two, earnings management may be an equilibrium outcome of the resultant agency conflict (e.g., Stein, 1989). Several papers examine drivers of the agency conflicts that contribute to earnings management incentives, such as compensation contracts-

\footnotetext{
${ }^{1}$ See, for example, investigations of earnings management around executive turnovers (Dechow and Sloan, 1991; Pourciau, 1993), proxy contests (DeAngelo, 1988), management buyouts (DeAngelo, 1986), initial public offerings (Teoh et al., 1998b; Darrough and Rangan, 2005), seasoned equity offerings (Teoh et al., 1998a; Shivakumar, 2000), and corporate borrowing (Beatty and Weber, 2003).
} 
e.g., bonus schemes (Healy, 1985), and stock and options holdings and issues (Bergstresser and Philippon, 2006; Coles et al., 2006b) - and CEO characteristics - e.g., CEO tenure (Ali and Zhang, 2015).

In this paper, we explore how managers opportunistically manage earnings around market participants' uncertainty about the firm, thus contributing to and linking the literatures on earnings management and the effect of economic uncertainty on firm decision making. To our knowledge, we are the first to explore how managers opportunistically manage earnings around market participants' uncertainty about the firm. Our findings have new implications for the role uncertainty may play in altering managerial decision making and reporting.

To motivate our study, Figure 1 plots the association between the aggregate level of earnings management - as measured by the percentage of firms reporting small profits to small losses over a given quarter (Burgstahler et al., 2006; Dechow et al., 2003) - and the level of economic uncertainty in the market - as measured by the VIX index. These time series reveal a striking pattern: In times of relatively low market-level uncertainty, there is a much greater relative propensity to generate small profits, consistent with managing earnings upward. In contrast, in times of relatively high market-level uncertainty, there is an increase in the relative likelihood of generating small losses, consistent with less upward earnings management.

One possible explanation for this aggregate empirical phenomenon is that uncertainty shocks tend to be countercyclical (e.g., Baker and Bloom, 2013). If uncertain times tend to be bad times, the business cycle may explain some of the association between uncertainty and losses (although it is less likely to explain the much higher relative likelihood of small losses). We focus on another explanation: the fact that managers may face incentives that lead them to systematically manage earnings downward during times of elevated uncertainty. 
Using firm-level variation in uncertainty about the firm's future prospects, we document that firms facing relatively higher levels of uncertainty report more negative discretionary accruals (DA). This main empirical finding is based on firms' equity option-implied volatility and the cross-sectional modified-Jones model (e.g., Bartov et al., 2000) augmented with return on assets (Kothari et al., 2005), but is robust to alternative measurements of uncertainty and earnings management and uncertainty. Overall, these empirical findings are consistent with firms managing earnings downward during uncertain times.

Consistent with the earnings-management hypothesis, we further document that the negative uncertainty-DA relation is most pronounced at firms whose CEOs have greater incentives to manage earnings (e.g., Bergstresser and Philippon, 2006; Core and Guay, 2002): that is, at firms (1) where the CEO's potential total compensation is more closely tied to the value of stock and option holdings, or (2) where the CEO is relatively early in her tenure, or (3) that face greater earnings pressures from market participants. Also consistent with earnings management, we find that the negative uncertainty-DA relation is more pronounced when the CEO enjoys greater ability to manage earnings. Specifically, this overall negative relation (as well as its mediating effects) is strongest in the period prior to the enactment of the Sarbanes-Oxley Act (SOX), which was designed to improve the quality of financial disclosures and discourage manipulative accounting practices.

In exploring potential mechanisms, we hypothesize that the negative uncertainty-DA relation reflects firms' strategic management of earnings based on the market's information environment. During times of market uncertainty, in particular, managers are more likely to manage earnings downward, since markets are more likely to attribute bad performance to luck or to expect performance at such times to be transient. Conversely, during times of relatively low uncertainty, firms are more likely to manage earnings upward since markets 
are more likely to attribute good performance to skill or to expect performance during such periods to be more persistent.

Consistent with this hypothesis, we find that market prices tend to be less sensitive to earnings consensus surprises during times of higher uncertainty; conversely, market prices tend to be more sensitive to earnings surprises during times of lower uncertainty. In other words, the earnings response coefficient (ERC) is higher during times of relatively low uncertainty and lower during times of relatively high uncertainty.

We further show that the negative uncertainty-DA relation appears to be driven by periods of relatively high volatility. In theory, as volatility rises above expected levels, firms have an incentive to manage earnings downward; to the degree that market participants recognize this incentive, they will place less weight on earnings announcements, lowering ERCs (Liang, 2004; DeFond and Park, 1997; Baber et al., 2006). This pattern reinforces managers' incentives to manage downward, steepening the negative uncertainty-DA relation. In contrast, when volatility drops below expected levels, high ERCs create an incentive to manage earnings upward. Market anticipation of this incentive again causes investors to ascribe lower weight to announced earnings (lowering ERCs), in this case offsetting - rather than reinforcing - the incentive to manage earnings. Thus the uncertainty-DA relation is accentuated at high levels of uncertainty and moderated at low levels. Consistent with this ERC channel, our empirical results show that the association between uncertainty and DA has a kink, with a steeper relation at relatively high levels of uncertainty and a flatter relation at lower levels. Overall, our results are novel in documenting that firms are more likely to manage earnings during more opportune times (times of elevated levels of uncertainty), particularly when managers face greater incentives or enjoy greater ability to do so.

The remainder of the paper is organized as follows. Section 2 presents a simple model 
based on Stein (1989) that illustrates the intuition behind several of our empirical results. Section 3 describes our data and estimation samples. Section 4 documents our main empirical findings on the association between uncertainty and discretionary accruals. Section 5 proposes a hypothesis and offers empirical evidence in support of a potential mechanism that explains our main empirical findings. Section 6 concludes.

\section{Illustrative Model}

To provide intuition for our empirical results, we draw on Stein's (1989) model of myopic corporate behavior. In this model, managers observe true or "natural" earnings $\left(e_{t}^{*}\right)$, consisting of both transient and persistent components, but may report earnings that differ. Market participants infer future payoffs based on the firm's history of reported earnings and set prices accordingly. Because market prices depend on reported earnings, and managers are assumed to be incentivized by both the short-run and the long-run value of the firm, managers have an incentive to manipulate earnings in the current period (i.e., to report earnings that deviate from the firm's "natural" earnings); such manipulation boosts the firm's short-run value but erodes long-run value. In choosing the optimal level of earnings management, therefore, the manager faces a tradeoff between short-run benefits and long-run costs to firm value. This model makes two predictions about this tradeoff that are relevant in our context. First, markets respond more strongly to the reported earnings of firms whose true earnings processes are characterized by little transitory noise ("lower uncertainty" firms). Second, the level of (upward) earnings management decreases with the level of uncertainty a firm faces. 


\subsection{Setup}

To begin, we define a firm's reported earnings and its true - but unobserved - earnings, and show how reported earnings are priced in the market. "True" or "natural" earnings $\left(e_{t}^{*}\right)$ consist of a permanent $\left(z_{t}\right)$ and a transitory component $\left(v_{t}\right)$, with permanent earnings following a random walk:

$$
\begin{aligned}
e_{t}^{*} & =z_{t}+v_{t}, \text { and } \\
z_{t} & =z_{t-1}+u_{t},
\end{aligned}
$$

where $\left(u_{t}, v_{t}\right)$ are IID mean zero with a positive semi-definite covariance matrix. ${ }^{2}$

Reported earnings $\left(e_{t}\right)$ are defined as the sum of true earnings and (upward) manipulation. Managers manipulate earnings by "borrowing" from the following period's earnings, but these "loans" $\left(b_{t}\right)$ come at a cost in terms of the manager's ability to engage in future manipulation. Specifically, reported earnings take the form

$$
e_{t}=e_{t}^{*}+b_{t}-c\left(b_{t-1}\right)
$$

where the convex function $c(\cdot)$ expresses the cost of inflating reported earnings in one period in terms of reported earnings foregone in the following period.

Finally, reported earnings are assumed to be immediately paid out as dividends (with no

\footnotetext{
${ }^{2}$ The assumption that the shocks are IID means that the model relies on comparative statics across firms with time-invariant uncertainty. Our empirical exercise diverges from the model in allowing firm-level uncertainty to vary over time.
} 
corporate taxes or dissipative costs), so that prices are discounted expected future earnings:

$$
P_{t}=\sum_{k=1}^{\infty} \frac{\mathbb{E}_{t}\left[e_{t+k}\right]}{(1+r)^{k}}=\sum_{k=1}^{\infty} \frac{\mathbb{E}_{t}\left[e_{t+k}^{*}+b_{t+k}-c\left(b_{t+k-1}\right)\right]}{(1+r)^{k}}
$$

The manager chooses earnings reports to maximize her utility, which is driven by short-run and long-run incentives. She is assumed to enter each period owning shares of her company's stock, and after that period's dividend payout to sell a fraction $\pi$ of her equity holdings, retaining the remainder indefinitely. ${ }^{3}$ Maximizing her expected discounted future payoffs is equivalent to maximizing

$$
U_{t}=e_{t}+\pi P_{t}+(1-\pi) \frac{\mathbb{E}_{t}\left[e_{t+1}\right]}{1+r}
$$

since earnings announcements in periods beyond $t+1$ are unaffected by the report chosen in period $t$. In this setting, short-run incentives come from dividends $\left(e_{t}\right)$ and the proceeds of share sales $\left(\pi P_{t}\right)$; long-run incentives come from the manager's remaining equity ownership in the firm, where $\pi$ is an exogenously determined compensation parameter that determines the extent to which managers respond to short-term pressures.

\subsection{Equilibrium and Comparative Statics}

In a steady-state signal-jamming equilibrium, managers will borrow a constant amount each period from the next period's earnings $(\bar{b})$, and the market will correctly anticipate this borrowing. In such an equilibrium, the true earnings process can be inferred from announced earnings

$$
\hat{e}_{t}^{*}=e_{t}+c(\bar{b})-\bar{b}
$$

\footnotetext{
${ }^{3}$ As Stein (1989) notes, this simplifying modeling assumption creates time inconsistency in the manager's decision but is not responsible for the model's main results.
} 
and the expectation of future (true) earnings is given by a weighted average of past imputed true earnings (as shown in Holmström, 1999): for all $k$,

$$
\mathbb{E}_{t}\left[e_{t+k}^{*}\right]=\sum_{j=0}^{\infty} a_{j} \hat{e}_{t-j}^{*}
$$

where

$$
\begin{aligned}
a_{0} & =\left(\kappa^{2} / 4+\kappa\right)^{1 / 2}-\kappa / 2, \text { and } \\
\kappa & =\sigma_{u}^{2} / \sigma_{v}^{2}
\end{aligned}
$$

This implies that market prices are a capitalized weighted average of past earnings reports: ${ }^{4}$

$$
P_{t}=\frac{1}{r}\left(\sum_{j=0}^{\infty} a_{j} e_{t-j}\right) .
$$

The parameter $\kappa$ is the ratio of the variances of the permanent and transitory components of true earnings. It measures how little transitory noise is captured in earnings: if, for example, all earnings innovations were transitory $\left(\sigma_{u}=0\right.$ and $\left.\kappa=0\right)$, current earnings would play no role in forming expectations about future earnings (i.e., $a_{0}=0$ ). Alternatively, we can interpret this parameter as capturing the level of uncertainty around a firm's earnings, and in particular their value relevance. For example, the proportion of the variation in "true"

$$
\begin{aligned}
& { }^{4} \text { To see this more clearly, } \\
& \begin{aligned}
P_{t}=\sum_{k=1}^{\infty} \frac{\mathbb{E}_{t}\left[e_{t+k}^{*}\right]+\bar{b}-c(\bar{b})}{(1+r)^{k}}=\sum_{k=1}^{\infty} \frac{\sum_{j=0}^{\infty} a_{j} \hat{e}_{t-j}^{*}+\bar{b}-c(\bar{b})}{(1+r)^{k}} \\
=\frac{1}{r}\left(\sum_{j=0}^{\infty} a_{j} \hat{e}_{t-j}^{*}+\bar{b}-c(\bar{b})\right)=\frac{1}{r}\left(\sum_{j=0}^{\infty} a_{j}\left[e_{t-j}+c(\bar{b})-\bar{b}\right]+\bar{b}-c(\bar{b})\right),
\end{aligned}
\end{aligned}
$$

which yields the result since the weights $\left(a_{j}\right)$ sum to one. 
earnings innovations that is explained by transitory shocks, $\frac{2 \sigma_{v}^{2}}{\operatorname{Var}\left(e_{t}^{*}-e_{t-1}^{*}\right)}=\frac{1}{1+0.5 \kappa^{2}}$, approaches 0 (1) as $\kappa$ increases (decreases). ${ }^{5}$ Thus, higher $\kappa$ corresponds to "greater certainty" in earnings in the sense that innovations in earnings are more likely to be persistent or value-relevant; lower $\kappa$ corresponds to "greater uncertainty" in earnings in the sense that earnings innovations are more likely to reflect noise and irrelevant for value.

Differentiating the pricing equation (10) with respect to $e_{t}$ and $\kappa$, we find that market prices react more positively to an increase in earnings when there is greater certainty:

$$
\frac{\partial^{2} P_{t}}{\partial e_{t} \partial \kappa}=\frac{1}{2 r}\left[\frac{\frac{2}{\kappa}+1}{\left(\frac{4}{\kappa}+1\right)^{1 / 2}}-1\right]>0 .
$$

This first result is intuitive, since firms with greater $\kappa$ are those whose earnings processes are characterized by less transitory noise. Earnings fluctuations are therefore more attributable to permanent shocks, and are more informative about future earnings (i.e., $a_{0}$ is higher) and firm value. For such firms, increasing earnings would provoke greater market responses than would comparable increases at firms with a low $\kappa$, where earnings are less informative about value. Section 5.1 considers related empirical tests.

Facing the equilibrium market pricing expressed in equation (10), the manager's utilitymaximizing earnings reports require (upward) manipulation that satisfies her first-order conditions:

$$
0=\frac{\partial e_{t}}{\partial b_{t}}+\frac{\partial P_{t}}{\partial b_{t}}+\frac{1-\pi}{1+r} \frac{\partial e_{t+1}}{\partial b_{t}}
$$

where $\frac{\partial e_{t}}{\partial b_{t}}=1$ and $\frac{\partial e_{t+1}}{\partial b_{t}}=c^{\prime}\left(b_{t}\right)$ follow from equation (3). Moreover, the market's pricing function implies that $\frac{\partial P_{t}}{\partial b_{t}}=\frac{a_{0}}{r}$. Holding constant the market's conjecture of earnings management $(\bar{b})$, increasing earnings management by one dollar results in a one-dollar

\footnotetext{
${ }^{5}$ The variance of "true" earnings innovations is given by $\operatorname{Var}\left(e_{t}^{*}-e_{t-1}^{*}\right)=\sigma_{u}^{2}+2 \sigma_{v}^{2}$.
} 
increase in the firm's inferred "true" earnings for the current period. By equation (7), current expectations of earnings increase by $a_{0}$ dollars in each future period, leading to a present-value effect of $\frac{a_{0}}{r}$.

The manager's choice of earnings management thus reflects the following tradeoff between her short-term and long-term incentives:

$$
\frac{1-\pi}{1+r} c^{\prime}\left(b^{*}\right)=1+\pi \frac{a_{0}}{r} .
$$

That is, the manager chooses a level of manipulation such that the long-term cost (in terms of the decline in next-period dividends) of a marginal dollar of manipulation equals the short-run gain (in the form of current-period dividends and stock-price response).

Most germane to the present study, this model predicts that this level of (upward) manipulation is increasing with the level of certainty in earnings innovations. The intuition is that, holding the market's conjecture fixed, when there is greater certainty (higher $a_{0}$ ), the short-run benefits of managing earnings upward are higher. Thus the optimal level of earnings management that balances the short- and long-run incentives is also higher, since the marginal (long-term) cost of manipulating is increasing with the level of manipulation. Our primary empirical tests, presented in Section 4, are motivated by the intuition provided in this model.

\section{Data and Sample}

Our analysis relies on data from a variety of standard sources, which we match to create firm-level panels at both (fiscal) yearly and quarterly frequencies. Our main estimates rely on data from five sources: financial statements and industry classifications from Compustat, options-implied volatility measures from OptionMetrics, executive-compensation data from 
ExecuComp, analysts' forecasts from the Institutional Brokers' Estimate System (I/B/E/S), and stock returns from the Center for Research in Security Prices (CRSP). Data on implied volatility is available beginning in 1996; we therefore analyze fiscal periods ending from January 1996 through March 2013. Our (unbalanced) panels consist of an average of 8 annual observations on each of 1,892 unique firms, and 26 quarterly observations on each of 2,104 firms.

Our main results, presented in Section 4, explore the relationship between firm-level uncertainty and earnings management. We measure earnings management using discretionary accruals, and uncertainty using the implied volatility of equity options. Our regression estimates include a variety of other control variables that may affect earnings management directly or mediate the effect of uncertainty.

Our key dependent measure is discretionary accruals, which are measured in two steps: (1) calculating total accruals, and (2) subtracting off an estimate of non-discretionary accruals. The second step involves regressing total accruals on a set of firm-level controls; we treat the fitted values as the non-discretionary component and the residuals as the discretionary one.

We calculate total accruals (normalized by beginning-of-period assets) using data from the statement of cash flows, following Hribar and Collins (2002). Total accruals are calculated as the difference between earnings before extraordinary items (IBC) and net cash flow from operating activities (OANCF) minus extraordinary items and discontinued operations (XIDOC), scaled by total assets (AT):

$$
\text { TotalAccruals }_{i, t}=\frac{\mathrm{IBC}_{i, t}-\left(\mathrm{OANCF}_{i, t}-\mathrm{XIDOC}_{i, t}\right)}{\mathrm{AT}_{i, t-1}} .
$$

Section 4.3 also considers a balance sheet-based measure of total accruals. 
Prior literature suggests a variety of estimation strategies for distinguishing discretionary from non-discretionary accruals. We use the modified-Jones model (as in Dechow et al., 1995), augmented with return-on-assets data and estimated in the cross-section (following Kothari et al., 2005). Total accruals are "predicted" as a linear function of revenue changes $(\triangle \mathrm{REVT})$ minus changes in accounts receivable $(\triangle \mathrm{RECT})$; the gross value of property, plant, and equipment (PPENT); and lagged operating income before depreciation (OIBDP):

$$
\begin{aligned}
& \mathbb{E}\left[\text { TotalAccruals }_{i, t}\right]= \\
& \quad \beta_{0}+\beta_{1} \frac{1}{\mathrm{AT}_{i, t-1}}+\beta_{2} \frac{\Delta \mathrm{REVT}_{i, t}-\Delta \mathrm{RECT}_{i, t}}{\mathrm{AT}_{i, t-1}}+\beta_{3} \frac{\operatorname{PPENT}_{i, t}}{\mathrm{AT}_{i, t-1}}+\beta_{4} \frac{\mathrm{OIBDP}_{i, t-1}}{\mathrm{AT}_{i, t-1}} .
\end{aligned}
$$

We estimate the coefficients of equation 14 separately for each period across all the Compustat firms in each two-digit SIC code-based industry. ${ }^{6}$ Discretionary accruals are the residuals from these regressions:

$$
\text { DiscretionaryAccruals }_{i, t}=\text { TotalAccruals }_{i, t}-\text { TotalAccruals }_{i, t} \text {. }
$$

Subramanyam (1996) and Bartov et al. (2000) discuss the benefits of estimating equation 14 in the cross-section, but in Section 4.3 we consider time-series estimates as well as models using alternate firm-level controls.

We measure firm-level uncertainty using the 91-day implied volatility of equity options as of the last day of the fiscal period. This measure is the annualized standard deviation of stock returns over the subsequent 91 days that is consistent with the market price of an exchange-traded equity option (we use at-the-money-forward calls); it is calculated by

\footnotetext{
${ }^{6}$ All variables in these regressions are winsorized outside the 0.5 th and 99.5 th percentiles of the pooled sample.
} 
OptionMetrics using an inversion of the Black-Scholes formula. Section 4.3 also considers alternative measures of firm-level uncertainty.

Bergstresser and Philippon (2006) and Efendi et al. (2006) suggest a number of controls that may help predict earnings management (though they consider different measures of earnings management than we do). Following them, our discretionary-accruals regressions control for market capitalization, book-to-market ratio, debt-to-asset ratio (winsorized above 1), lagged inverse-interest coverage ratio, ${ }^{7}$ a binary indicator for whether the CEO is also the board chair, and the CEO's compensation-based incentive to manage earnings. Variables are defined in Table 1.

To shed light on the mechanism underlying our main results on the association between uncertainty and earnings management, we also consider whether the market response to an earnings announcement varies systematically with the level of uncertainty. These results, presented in Section 5.1, rely on analyst-forecast data from I/B/E/S and stock-return data from CRSP. Earnings are assumed to have been announced on the earlier of the dates reported by I/B/E/S and Compustat. ${ }^{8}$ We consider the deviation of announced earnings from the median analyst forecast (made at least 30 days before the announcement), normalized either by the share price 21 days before the announcement or by total assets. These earnings-surprise measures are winsorized outside the 0.5 th and 99.5 th percentiles. Finally, we consider stock returns over the 4- and 21-trading-day windows that end the day after earnings are announced.

Inclusion in our samples require the availability of all the variables described above. (Given limited data availability, several additional results and robustness tests are performed

\footnotetext{
${ }^{7}$ The inverse-interest coverage ratio is defined as interest expense divided by operating income before depreciation, winsorized above 2 , and set to 2 if operating income before depreciation is negative.

${ }^{8}$ This resolution of disagreements about announcement dates follows DellaVigna and Pollet (2009), who find that the earlier date is usually correct; the later date tends to reflect that of publication in the Wall Street Journal.
} 
on restricted samples.) Summary statistics for the annual and quarterly samples are reported in Table 2.

\section{Empirical Analysis and Results}

\subsection{Uncertainty and Discretionary Accruals}

We assesses the overall association between firm-level uncertainty and discretionary accruals by estimating equations of the form

$$
\text { DiscretionaryAccruals }_{i, t}=\alpha+\beta \text { ImpliedVolatility }_{i, t}+\gamma \cdot \mathbf{X}_{i, t}+f_{t}+\epsilon_{i, t},
$$

where $i$ indexes firms and $t$ indexes time periods. The inclusion of time fixed effects $f_{t}$ serves to control for (homogeneous) time-variation in the level of discretionary accruals, such

that our key parameter estimates $\hat{\beta}$ are identified by cross-sectional variation in uncertainty and discretionary accruals. In most specifications, the vector of controls $\mathbf{X}_{i, t}$ includes crosssectional fixed effects, at either the industry level or the firm level. We also control for a number of (potentially time-varying) firm-level determinants of discretionary accruals as described in Section 3 and defined in Table 1: market capitalization, book-to-market ratio, debt-to-asset ratio, inverse interest coverage, and whether the CEO chairs the board. We also control for a lagged measure of CEOs' incentive to manage earnings proposed by Bergstresser and Philippon (2006). ${ }^{9}$

Table 3 reports the results of estimating equation 16 on our annual sample. All the estimates include time fixed effects at the calendar quarter level, while the specifications

\footnotetext{
${ }^{9}$ To construct this measure, we begin by considering the effect of a 1-percent increase in share price on $\mathrm{CEO}$ wealth (under the assumption that her options holdings have a delta of one):

$$
\text { OnePercent }_{i, t-1}=\left(0.01 \times \text { Price }_{i, t-1}\right)\left(\text { CEOshares }_{i, t-1}+\text { CEOoptions }_{i, t-1}\right) .
$$


vary in their inclusion of cross-sectional fixed effects: column 1-our "baseline" specificationincludes industry fixed effects, column 2 removes them, and column 3 replaces them with firm-level fixed effects. In all cases, standard errors are two-way cluster robust by firm and time period (Petersen, 2009).

Our main coefficient of interest on implied volatility is negative and statistically significant at conventional levels in all specifications. This negative coefficient indicates that firms tend to take lower/more negative discretionary accruals (consistent with downward earnings management) during periods of heightened uncertainty, and larger/more positive discretionary accruals (consistent with upward management) when uncertainty is low. For example, the coefficient estimates in column 1 suggest that a median firm experiencing a one-standarddeviation decline in the uncertainty distribution (11.8\%) would increase discretionary accruals by an amount equal to $0.83 \%$ of total assets. ${ }^{10}$ Relative to the median (operating) ROA in our sample of $4.8 \%(13.7 \%)$, this effect represents a $17.4 \%$ (7.0\%) proportional increase, which is an economically meaningful effect. These magnitudes are consistent with the size of the economic effects on earnings management documented in other studies (e.g., Klein, 2002; Cheng and Warfield, 2005), as well as the findings of Dichev et al. (2013), whose field survey suggests that about $10 \%$ of reported earnings (i.e., in absolute value) are managed.

To further assess the magnitudes of our estimates of the effects of uncertainty on DA, Table 4 compares them to the effects of uncertainty on two related measures: total accruals The CEO manipulation incentive is defined as the fraction of the CEO's total annual gains (wealth effect plus compensation) that would come from this 1-percent share-price increase:

CEO manipulation incentive $(\mathrm{BP} 2006)=$

$$
\frac{\text { OnePercent }_{i, t-1}}{\text { OnePercent }_{i, t-1}+\text { CEOsalary }_{i, t-1}+\text { CEObonus }_{i, t-1}} .
$$

\footnotetext{
${ }^{10}$ Our estimates are computed from the cross-sectional median of the within-firm standard deviation for all firms in our estimation sample.
} 
( $T A$, in column 2) and change-in-working-capital accruals ( $\triangle \mathrm{WC}$, in column 3). Column 1 replicates our result for DA (Table 3, column 1) using the subsample for which all three dependent variables of interest are defined. Comparing columns 1 and 2 in Table 4, we find an uncertainty-DA relation (of -0.072 and significant at the $1 \%$ level) that is smaller than the overall relation between uncertainty and TA (of -0.01 that is also significant at the $1 \%$ level). Because uncertainty is countercyclical and because the estimation of DA in equation (14) removes the effect of business cycles on accruals, our finding of a greater uncertainty-TA association is expected.

Column 3 in Table 4 considers a particular component of TA: working-capital accruals. The effects of uncertainty on working-capital accruals is examined in the recent work of Arif et al. (2015). Consistent with their main findings, our regression obtains a significant (at the $10 \%$ level) coefficient on uncertainty of $-0.01 .^{11}$

\subsection{Heterogeneous Effects: Executive Incentives and the Sarbanes- Oxley Act}

This section provides additional evidence that the overall relation between uncertainty and DA is consistent with the earnings-management hypothesis. Our analysis exploits crosssectional variations in managers' incentives and ability to engage (or the cost of engaging) in earnings management. Under the earnings-management hypothesis, managers with greater incentives (and greater abilities) to manage earnings should exhibit a stronger negative uncertainty-DA relation; we investigate whether the negative uncertainty-DA relation varies systematically with measures of CEO incentives and abilities to manage earnings (or the

\footnotetext{
${ }^{11}$ The main tests of Arif et al. (2015) regress changes in working capital on expected daily volatility, estimated using a GARCH(1,1) model. To compare their coefficient to ours (which is based on annualized volatility), we divide their estimated effects by $\sqrt{252}$. Applying this method to Table 4 , column 4 in their paper gives an estimated effect of annualized volatility on $\Delta \mathrm{WC}$ of -0.014 , similar to our estimate in Table 4 .
} 
costs of doing so). To do so, we modify our estimation equation to include an interaction between implied volatility and a control variable $z$ :

$$
\begin{aligned}
& \text { DiscretionaryAccruals }_{i, t}= \\
& \qquad \alpha+\beta \text { ImpliedVolatility }_{i, t}+\lambda z_{i, t}+\mu \text { ImpliedVolatility }_{i, t} z_{i, t}+\gamma \cdot \mathbf{X}_{i, t}+f_{t}+\epsilon_{i, t} .
\end{aligned}
$$

\subsubsection{Executive Incentives}

Our first set of tests for earnings management is based on the idea that strategic earnings management may be more attractive when (1) a manager's compensation is more closely linked to the company's stock price, (2) the manager's tenure is relatively short, and (3) shortterm performance pressures are relatively strong. When compensation is more closely linked to stock prices, the CEO's financial rewards for earnings management increase. ${ }^{12}$ When the CEO is relatively early in her tenure, she may have greater incentives to manage earnings because markets have less precise signals about her abilities (Ali and Zhang, 2015). Finally, when a manager faces greater short-term performance pressures, she may be more likely to manage earnings in response.

When executives face greater incentives to manage earnings, we expect the DA-volatility relation to be stronger (that is, more negative). To test these predictions, Table 5 allows the effect of volatility on discretionary accruals to vary with incentives. As in the prior tables, our main measure of an executive's compensation incentives $\left(\right.$ incentive $_{t-1}$ ) measures how closely compensation is tied to the company's stock price (following Bergstresser and Philippon, 2006). We measure tenure as the length in years of the CEO's current term.

\footnotetext{
${ }^{12}$ Alternatively, the market might anticipate greater earnings management when CEO compensation is more closely linked to stock prices. In a Stein-type (1989) Nash equilibrium, managers with such compensation contracts manage earnings more, though financial rewards are not necessarily higher since markets are not fooled.
} 
To proxy for the extent of an executive's sensitivity to short-term performance pressures, we rely on analyst coverage (numest) - the number of analysts covering the firm - and the fraction of shares held by institutional owners (ior). All else equal, we expect managers to face greater short-term performance pressure when the company garners more market attention and is covered by more analysts; conversely, we expect managers to face milder short-term performance pressure when institutional investors account for a larger proportion of the company's shareholdings (e.g., Bushee, 1998).

The empirical tests of Table 5 include these executive-incentive variables to control for their main effects on discretionary accruals, but our primary coefficients of interest are their interactions with volatility, which indicate the effect of executive earnings management incentives on the DA-volatility relation. Column 1 in Table 5 considers incentives to manage earnings stemming from compensation and tenure, and in both cases we find that the DAvolatility relation is strengthened (more negative) when the manager has more pronounced incentives (i.e., due either to compensation more closely tied to stock prices or to shorter tenure).

As discussed above, the compensation incentive measure calculates the effect of a 1-percent increase in share price on $\mathrm{CEO}$ wealth, and then calculates the fraction this represents of the CEO's total annual gains (from both compensation, and stock and options appreciation). As implemented in Bergstresser and Philippon (2006), this measure assumes that an increase in stock price leads to a dollar-for-dollar increase in the value of the CEO's options - that is, that the options have a delta of one. Since this would only be true if the options' strike price were zero, we also consider an adjusted incentive measure based on an estimated option delta as suggested in Core and Guay (2002) (and implemented using code from Coles et al., 
2006a). ${ }^{13}$ Column 2 replicates the results of the first column using this adjusted measure, and obtains results both economically and statistically similar.

Column 3 considers incentives to manage earnings stemming from short-term performance pressures. Consistent with the idea that heavier analyst coverage and lower institutional holdings indicate greater short-term performance pressures, we find a negative and significant (at the $5 \%$ level) interaction coefficient between volatility and analyst coverage, as well as a positive and significant (at the 10\% level) interaction coefficient for institutional ownership. Columns 4 and 5 combine the executive-incentive and short-term performance pressure tests in single estimates.

\subsubsection{Ability to Engage in Earnings Management}

Our second set of heterogeneous-effects tests is based on the idea that strategic earnings management may be more attractive when managers enjoy greater ability to manage earnings or when the costs of doing so are lower. We exploit the introduction of the Sarbanes-Oxley Act (SOX), which reduced managers' abilities to engage in earnings management by improving the quality of financial disclosures and increasing the cost of earnings manipulation (Cohen et al., 2008).

Columns 1 and 3 in Table 6 replicate Table 3's main specification (i.e., column 1) for the pre2004 period, before SOX was implemented, and the post-2004 period, after implementation. The coefficient of interest, implvol, is statistically significant at the $1 \%$ level as well as economically significant; the magnitude of the coefficient is larger than our baseline results in

\footnotetext{
${ }^{13}$ The effect of a one-percent increase in share price on CEO wealth calculated in equation 17 is therefore replaced with

$$
\text { OnePercent }_{i, t-1}^{\text {adjusted }}=\left(0.01 \times \text { Price }_{i, t-1}\right)\left(\text { CEOshares }_{i, t-1}+\Delta \text { CEOoptions }_{i, t-1}\right) .
$$

which is used as in equation 18 to calculate the adjusted CEO earnings management incentive measure.
} 
Table 3. In contrast, column 3 suggests that the uncertainty-DA relation has attenuated substantially post-SOX, in terms of both magnitude (a reduction of 45\%) and statistical significance (now at the $10 \%$ level).

Columns 2 and 4 replicate the executive-incentive tests of the previous section (Table 5, column 4) for the pre- and post-SOX periods, respectively. In the pre-SOX period, the negative uncertainty-DA relation tends to be stronger when managers face greater incentives to manipulate earnings (due to compensation, tenure, or degree of external pressure). In the post-SOX period, the effects of these incentives on earnings management around uncertainty are no longer statistically significant. Overall, these results suggest that the uncertainty-DA relation was more pronounced during the pre-SOX era, consistent with the thesis that the relation reflecting earnings management around uncertainty.

\subsection{Robustness}

\subsubsection{Alternative Measures of Discretionary Accruals and Sample Timing}

As described in Section 3, our main measure of earnings management is discretionary accruals, which we calculate using the modified-Jones model augmented with return on assets, estimated in the cross-section using a cash-flow-based measure of total accruals. The negative association between implied volatility and discretionary accruals documented in Section 3 is robust to the use of a variety of alternative ways of measuring discretionary accruals, which we document in columns $1-5$ of Table 7 . Note that some measures require data that is not available for all the observations in our main analysis sample; we include results on a consistent sample for which all the discretionary accrual measures can be calculated, and re-estimate our baseline specification on this restricted sample in column 1.

In columns $2-3$, we make two modifications to our baseline discretionary accruals measure 
that are common in the earnings management literature. Column 2 relies on a prediction of nondiscretionary accruals made without adjusting revenue changes for changes in accounts receivable, replacing equation 14 with

$$
\mathbb{E}\left[\text { TotalAccruals }_{i, t}\right]=\beta_{0}+\beta_{1} \frac{1}{\mathrm{AT}_{i, t-1}}+\beta_{2} \frac{\Delta \mathrm{REVT}_{i, t}}{\mathrm{AT}_{i, t-1}}+\beta_{3} \frac{\operatorname{PPENT}_{i, t}}{\mathrm{AT}_{i, t-1}}+\beta_{4} \frac{\mathrm{OIBDP}_{i, t-1}}{\mathrm{AT}_{i, t-1}}
$$

This is the Jones (1991) model augmented with return on assets, which (as with our baseline model) we estimate in the cross-section using a cash-flow-based total accruals measure. Column 3 replicates our baseline measure, but calculates total accruals (normalized by beginning-of-period assets) using data from the balance sheet rather than the statement of cash flows. Here, total accruals are the change in current assets minus the change in current liabilities (excluding long-term debt in current liabilities), the change in cash holdings, and depreciation and amortization:

$$
\operatorname{TotalAccruals}_{i, t}=\frac{\Delta \mathrm{ACT}_{i, t}-\left(\Delta \mathrm{LCT}_{i, t}-\Delta \mathrm{DLC}_{i, t}\right)-\Delta \mathrm{CHE}_{i, t}-\mathrm{DP}_{i, t}}{\mathrm{AT}_{i, t-1}}
$$

In columns $4-5$ we consider two modifications to our baseline discretionary accruals measure, in line with Dechow et al. (1995). Discretionary accruals in column 4 are estimated without return on assets as a predictor of nondiscretionary accruals; this modified-Jones model replaces equation 14 with

$$
\mathbb{E}\left[\text { TotalAccruals }_{i, t}\right]=\beta_{0}+\beta_{1} \frac{1}{\mathrm{AT}_{i, t-1}}+\beta_{2} \frac{\Delta \mathrm{REVT}_{i, t}-\Delta \mathrm{RECT}_{i, t}}{\mathrm{AT}_{i, t-1}}+\beta_{3} \frac{\mathrm{PPENT}_{i, t}}{\mathrm{AT}_{i, t-1}}
$$

which we estimate in the cross-section using a cash-flow-based total accruals measure. Column 5 estimates the same modified-Jones model using a separate time series for each firm. 
In each case, the negative association we found with our baseline discretionary accrual measure also exists with these alternatives, with each specification achieving statistical significance at the $1 \%$ level. The last two columns of Table 7 replicate the baseline estimate from Section 4.1 on alternate samples. Column 7 restricts the annual sample to observations with fiscal years ending in December. The parameter estimate for implied volatility is nearly unchanged. Finally, column 8 is estimated using the quarterly sample. Again, we find a highly statistically significant negative relation between uncertainty and discretionary accruals, with a magnitude roughly one-quarter of what we found using annual data. Overall, we find a significantly negative association between discretionary accruals and economic uncertainty that is robust to various alternative measurements of discretionary accruals and alternative sample timing.

\subsubsection{Alternative Measures of Uncertainty}

We also consider four alternative measures of firm-level uncertainty in addition to implied volatility: (1) the standard deviation in analysts' forecasts, observed on the date immediately prior to the earnings announcement, scaled by the stock price 21 days prior (stdevest_pr21); (2) the standard deviation in analysts' forecasts scaled by total assets observable 21 days prior to the earnings announcement (stdevest_ass21); (3) the standard deviation of the firm's realized daily stock returns over the preceding fiscal year (lag_avg_volr); and (4) the standard deviation of the firm's realized daily stock returns over the current fiscal year (avg_volr).

Table 8 reports the primary specification of Table 3 using implied volatility (column 1) and the four alternative measures of firm-level uncertainty (columns 2-5) as the main explanatory variable of interest. Each regression is estimated using a common sample of firms for which all five alternative uncertainty measures are observed. Across the board, we find a consistently negative and significant association between DA and uncertainty, suggesting 
that our inferences about the uncertainty-DA relation are robust to various measurements of firm-level uncertainty.

\section{Mechanism}

\subsection{Uncertainty and the Market Response to Earnings Announce- ments}

In Section 4, we documented the negative association between firm-level uncertainty and discretionary accruals, and showed that this association is stronger when managers have stronger incentives or greater ability to manage earnings. This section considers why uncertainty could create an incentive to manage earnings downward.

Announced earnings is a signal of firm value, and surprises in announced earnings (relative to prior expectations) lead to share-price movements. The strength of the anticipated market response, or the earnings response coefficient (ERC), may determine the manager's incentives to manage earnings. In particular, during high-uncertainty periods, market participants can be expected to be more likely to attribute earnings surprises to luck rather than persistent firm performance (e.g., due to managerial skill), suggesting a lower ERC. In contrast, during low-uncertainty periods, market participants can be expected to be more likely to attribute earnings surprises to persistent firm performance rather than luck, suggesting a higher ERC. If managers anticipate this systematic relation between uncertainty and the strength of earnings responses, they have an incentive to take more negative accruals during uncertain times when the firm's share price will suffer a smaller "penalty" for relatively low earnings. Doing so allows managers to take more positive accruals and announce higher earnings when uncertainty is low, precisely when these earnings are more heavily rewarded with 
announcement returns.

To test this ERC mechanism, we examine the association between uncertainty and earnings response coefficients. In particular, we consider the effect of announced earnings (relative to analysts' consensus forecast) on stock returns during a windows around the earnings announcement date, allowing this coefficient to vary systematically with the level of uncertainty. We therefore estimate models of the form

$$
\begin{aligned}
{\text { Announcement } \operatorname{return}_{i, t}=\alpha+} & \beta \operatorname{ImpVol}_{i, t}+\lambda \frac{\text { Earnings }_{i, t}-\text { Forecast }_{i, t}}{\text { Price }_{i, t}} \\
& +\mu \frac{\text { Earnings }_{i, t}-\text { Forecast }_{i, t}}{\text { Price }_{i, t}} \operatorname{ImpVol}_{i, t}+\gamma \cdot \mathbf{X}_{i, t}+f_{t}+\epsilon_{i, t},
\end{aligned}
$$

where $i$ indexes firms and $t$ indexes time periods. In our baseline specification, announcement returns are calculated over a window beginning three days before the earnings announcement and ending the day after the announcement. The earnings-announcement surprise relative to the consensus forecast is normalized by the share price 21 days before the announcement date. Implied volatility and the other controls $(\mathbf{X})$ are the same as in our earlier regressions. All variables are calculated as described in Section 3.

The results from estimating the above equation on our quarterly estimation sample appear in Table 9. Column 1 includes industry fixed effects, which are omitted in column 2 and replaced with firm fixed effects in column 3. In column 4, we normalize consensus forecast surprise by total assets rather than share price. In column 5 we consider returns over a longer window beginning 20 days before the earnings announcement.

The coefficient on earnings surprise, $\lambda$, represents the earnings response coefficient if volatility were (counterfactually) zero. Unsurprisingly, this value is positive and highly significant in all specifications: higher earnings announcements result in higher stock returns. 
Our main coefficient of interest is $\mu$, the coefficient on the interaction of surprise and volatility. The negative estimates in all specifications show that ERCs are lower when uncertainty is higher, in line with the mechanism hypothesized above. For example, using the coefficient estimates from column one, a firm at the 75 th percentile of the uncertainty distribution (implied volatility of $50.4 \%$ ) faces an ERC of 1.88; that is, increasing announced quarterly earnings by $1 \%$ of the firm's market capitalization generates announcement returns of $1.88 \%$. In contrast, a firm at the 25th percentile of the uncertainty distribution (28.6\%) has an ERC of 2.31 , which is $23 \%$ higher than the "high-uncertainty" firm's. ${ }^{14}$

One question raised by the mechanism hypothesized in this section is whether market participants understand the incentive to manage earnings down in uncertain times and up in less uncertain periods. If so, they should anticipate lower earnings when uncertainty is high, delivering a higher announcement return even in the absence of an earnings surprise relative to the consensus forecast. Indeed, we estimate statistically significant positive coefficients on implied volatility in all specifications, consistent with the fact that the announcement returns of firms that exactly meet the forecast are higher for high-volatility firms than for low-volatility firms. Although other explanations could drive this pattern (most notably that the higher returns are compensation for risk), it is consistent with market participants' adjusting their earnings expectations in light of managerial incentives.

\footnotetext{
${ }^{14}$ Using estimates from the other specifications, we find that the low-uncertainty firm's ERC is $21-28 \%$ higher than the high-uncertainty firm's. Furthermore, our model generates positive ERCs (as expected) for even very high levels of uncertainty (at least 1.29 in all specifications).
} 


\subsection{Nonlinearity of the Uncertainty-Earnings Management Rela- tionship}

We have shown that the share-price response to earnings announcements is stronger when uncertainty is lower, consistent with market participants' greater attribution of these earnings to persistent firm performance. This would provide incentives to manage earnings upward in low-uncertainty periods and downward when uncertainty is high. If market participants anticipate this incentive, however, they may place less weight on earnings announcements across the board, lowering ERCs. For high-volatility firms, this dynamic reinforces the incentive to manage earnings down, since both uncertainty and the anticipation of earnings management moderate the "penalty" for low earnings. In contrast, lower ERCs due to anticipation offset the high ERCs that encourage low-volatility firms to manage earnings upward in search of high announcement returns.

Since anticipation of earnings management should steepen the uncertainty-DA relation for high-uncertainty firms but flatten it for low-uncertainty firms, we hypothesize that the uncertainty-DA relation should be nonlinear in uncertainty. To investigate this hypothesis, we consider a modification of the linear uncertainty-accruals estimates reported in Section 4.1, allowing the effect of volatility to vary based on whether it is at a "higher-than-expected" or "lower-than-expected" level.

We first estimate the "expected" level of volatility as a linear function of all our other control variables (including fixed effects):

$$
\mathbb{E}\left[\text { ImpliedVolatility }{ }_{i, t}\right]=\alpha^{\mathrm{vol}}+\gamma^{\mathrm{vol}} \cdot \mathbf{X}_{i, t}+f_{t}^{\mathrm{vol}}
$$

After estimating the coefficients of this equation using OLS, we use the fitted values to 
calculate residual volatility,

$$
\text { VolatilityResidual }_{i, t}=\text { ImpliedVolatility }_{i, t}-\text { Implie } \widehat{\mathrm{dVolat}}_{\mathrm{I}_{i}} \mathrm{Ity}_{i, t},
$$

which we use to re-estimate the relationship between volatility and discretionary accruals.

Merely replacing volatility in our original estimating equation (equation 16) with this volatility residual would give the same parameter estimates (per the Frisch-Waugh-Lovell Theorem). Here, however, we allow the effect to vary depending on whether volatility is above or below its expectation (i.e., VolatilityResidual ${ }_{i, t} \gtrless 0$ ):

$$
\begin{aligned}
& \text { DiscretionaryAccruals }_{i, t}= \\
& \qquad \alpha+\beta \text { VolatilityResidual }_{i, t}+\lambda \max \left\{0, \text { VolatilityResidual }_{i, t}\right\}+\gamma \cdot \mathbf{X}_{i, t}+f_{t}+\epsilon_{i, t} .
\end{aligned}
$$

The coefficient $\beta$ then gives us the slope of the uncertainty-discretionary accrual relationship when volatility is below its expected value (conditional on controls), while $\beta+\lambda$ gives us the slope at above-expected volatility. Our hypotheses of a steeper uncertainty-DA relation would suggest a negative and significant $\lambda$.

Table 10 reports our estimation results. We find that the coefficient on the volatility residual $(\beta)$ is statistically indistinguishable from zero, suggesting that volatility has no significant relationship with discretionary accruals in the below-expected-volatility state. In contrast, the negative and significant coefficients on the positive volatility residual $(\lambda)$ indicate the presence of a statistically significant "kink" in the uncertainty-DA relation. Consistent with our conjecture, the results suggest that discretionary accruals fall with volatility as it increases above its expected level. Thus, the negative association between uncertainty and discretionary accruals appears to be driven by periods of relatively high uncertainty. This 
pattern is consistent with the mechanism hypothesized above: uncertain times' low ERCs encourage downward earnings management, and anticipation of this management further lowers ERCs, reinforcing the incentive.

\section{Conclusion}

There is increasing evidence and understanding of how economic uncertainty affects firm-level decision-making and aggregate outcomes. Our paper provides the first evidence on how market participants' uncertainty about firms' future prospects affect managerial decisions in financial reporting.

We document that firms report more negative discretionary accruals when financial markets are less certain about their future prospects. Consistent with markets being more likely to attribute performance to luck during uncertain periods, we find that stock-price responses to consensus forecast surprises are lower at those times. This pattern creates incentives for managers to boost earnings during lower-uncertainty periods and to create reserves during higher-uncertainty periods. Overall, we find that this phenomenon is more pronounced at firms whose executives have greater incentives to manage earnings to boost stock prices.

The analyses in this paper rely on the standard variants of discretionary accruals models common in the earnings-management literature (e.g., Jones, 1991; Dechow and Dichev, 2002; Kothari et al., 2005). Though beyond the scope of the current paper, our work can be extended by examining alternative outcomes that speak to earnings management, and in particular that distinguish between real and accrual earnings management. We believe these to be fruitful extensions of this line of inquiry and look forward to these new research opportunities. 


\section{References}

Ali, Ashiq, and Weining Zhang, 2015, CEO tenure and earnings management, Journal of Accounting and Economics 59, 60-79.

Arif, Salman, Nathan Marshall, and Teri Lombardi Yohn, 2015, Understanding the relation between accruals and volatility: A real options-based investment approach, Working paper, University of Indiana.

Baber, William R., Chen Shuping, and Sok Hyon Kang, 2006, Stock price reaction to evidence of earnings management: Implications for supplementary financial disclosure, Review of Accounting Studies 11, 5-19.

Bachmann, Rüdiger, and Christian Bayer, 2014, Investment dispersion and the business cycle, American Economic Review 104, 1392-1416.

Baker, Scott R, and Nicholas Bloom, 2013, Does uncertainty reduce growth? Using disasters as natural experiments, Working paper, National Bureau of Economic Research.

Bartov, Eli, Ferdinand A. Gul, and Judy S. L. Tsui, 2000, Discretionary-accruals models and audit qualifications, Journal of Accounting and Economics 30, 421-452.

Basu, Susanto, and Brent Bundick, 2012, Uncertainty shocks in a model of effective demand, Working paper, National Bureau of Economic Research.

Beatty, Anne, and Joseph Peter Weber, 2003, The effects of debt contracting on voluntary accounting methods changes, The Accounting Review 78, 119-142.

Bergstresser, Daniel, and Thomas Philippon, 2006, CEO incentives and earnings management, Journal of Financial Economics 80, 511-529.

Bianchi, Francesco, Cosmin Ilut, and Martin Schneider, 2014, Uncertainty shocks, asset supply and pricing over the business cycle, Working paper, National Bureau of Economic Research.

Bidder, Rhys M., and Matthew E. Smith, 2012, Robust animal spirits, Journal of Monetary Economics 59, 738-750.

Bloom, Nicholas, 2009, The impact of uncertainty shocks, Econometrica 77, 623-685.

Bloom, Nicholas, Max Floetotto, Nir Jaimovich, Itay Saporta-Eksten, and Stephen Terry, 2011, Really uncertain business cycles, Working paper, National Bureau of Economic Research. 
Burgstahler, David C., Luzi Hail, and Christian Leuz, 2006, The importance of reporting incentives: Earnings management in European private and public firms, The Accounting Review 81, 983-1016.

Bushee, Brian J., 1998, The influence of institutional investors on myopic R\&D investment behavior, The Accounting Review 73, 305-333.

Cheng, Qiang, and Terry Warfield, 2005, Equity incentives and earnings management, The Accounting Review 80, 441-476.

Christiano, Lawrence, Roberto Motto, and Massimo Rostagno, 2013, Risk shocks, Working paper, National Bureau of Economic Research.

Cohen, Daniel A., Aiyesha Dey, and Thomas Z. Lys, 2008, Real and accrual-based earnings management in the pre- and post-Sarbanes-Oxley periods, The Accounting Review 83, $757-787$.

Coles, Jeffrey L., Naveen D. Daniel, and Lalitha Naveen, 2006a, Managerial incentives and risk-taking, Journal of Financial Economics 79, 431-468.

Coles, Jeffrey L., Michael Hertzel, and Swaminathan Kalpathy, 2006b, Earnings management around employee stock option reissues, Journal of Accounting and Economics 41, 173-200.

Core, John E., and Wayne R. Guay, 2002, Estimating the value of employee stock option portfolios and their sensitivities to price and volatility, Journal of Accounting Research 40, 613-630.

Darrough, Masako N., and Srinivasan Rangan, 2005, Do insiders manipulate earnings when they sell their shares in an initial public offering, Journal of Accounting Research 43, 1-33.

DeAngelo, Linda Elizabeth, 1986, Accounting numbers as market valuation substitutes: A study of management buyouts of public stockholders, The Accounting Review 61, 400-420.

DeAngelo, Linda Elizabeth, 1988, Managerial competition, information costs, and corporate governance: The use of accounting performance measures in proxy contests, Journal of Accounting and Economics 10, 3-36.

Dechow, Patricia M, and Ilia D. Dichev, 2002, The quality of accruals and earnings: The role of accrual estimation error, The Accounting Review 77, 61-69.

Dechow, Patricia M., Scott A. Richardson, and Irem A. Tuna, 2003, Why are earnings kinky? An examination of the earnings management explanation, Review of Accounting Studies 8, $355-384$. 
Dechow, Patricia M., and Richard G. Sloan, 1991, Executive incentives and the horizon problem, Journal of Accounting and Economics 14, 51-89.

Dechow, Patricia M, Richard G Sloan, and Amy P. Sweeney, 1995, Detecting earnings management, The Accounting Review 70, 193-225.

DeFond, Mark L., and Chul W. Park, 1997, Smoothing income in anticipation of future earnings, Journal of Accounting and Economics 23, 115-139.

DellaVigna, Stefano, and Joshua M. Pollet, 2009, Investor inattention and Friday earnings announcements, Journal of Finance 64, 709-749.

Dichev, Ilia D., John R. Graham, Campbell R. Harvey, and Shiva Rajgopal, 2013, Earnings quality: Evidence from the field, Journal of Accounting and Economics 56, 1-33.

Dixit, Avinash K., and Robert S. Pindyck, 1994, Investment under uncertainty (Princeton University Press).

Efendi, Jap, Anup Srivastava, and Edward P. Swanson, 2006, Why do corporate managers misstate financial statements the role of option compensation, corporate governance, and other factors, Journal of Financial Economics 83, 667-708.

Glushkov, Denys, Rabih Moussawi, and Luis Palacios, 2009, Institutional ownership, concentration, and breadth ratios using Thomson Reuters $13 \mathrm{~F}$ data, Research Guide TR-13F, Wharton Research Data Services.

Graham, John R., Campbell R. Harvey, and Shiva Rajgopal, 2005, The economic implications of corporate financial reporting, Journal of Accounting and Economics 40, 3-73.

Gulen, Huseyin, and Mihai Ion, 2016, Policy uncertainty and corporate investment, Review of Financial Studies 29, 523-564.

Healy, Paul M., 1985, The effect of bonus schemes on accounting decisions, Journal of Accounting and Economics 7, 85-107.

Holmström, Bengt, 1999, Managerial incentive problems: A dynamic perspective, Review of Economic Studies 66, 169-182.

Hribar, Paul, and Daniel W. Collins, 2002, Errors in estimating accruals: Implications for empirical research, Journal of Accounting Research 40, 105-134.

Jones, Jennifer J., 1991, Earnings management during import relief investigations, Journal of Accounting Research 29, 193-228. 
Julio, Brandon, and Youngsuk Yook, 2012, Political uncertainty and corporate investment cycles, Journal of Finance 67, 45-83.

Klein, April, 2002, Economic determinants of audit committee independence, The Accounting Review 77, 435-452.

Kothari, S. P., Andrew J. Leone, and Charles E. Wasley, 2005, Performance matched discretionary accrual measures, Journal of Accounting and Economics 39, 163-197.

Liang, Pierre Jinghong, 2004, Equilibrium earnings management, incentive contracts, and accounting standards, Contemporary Accounting Research 21, 685-718.

Pastor, Lubos, and Pietro Veronesi, 2012, Uncertainty about government policy and stock prices, Journal of Finance 67, 1219-1264.

Petersen, Mitchell A., 2009, Estimating standard errors in finance panel data sets: Comparing approaches, Review of Financial Studies 22, 435-480.

Pindyck, Robert S., 1993, Investments of uncertain cost, Journal of Financial Economics 34, $53-76$.

Pourciau, Susan, 1993, Earnings management and nonroutine executive changes, Journal of Accounting and Economics 16, 317-336.

Shivakumar, Lakshmanan M., 2000, Do firms mislead investors by overstating earnings before seasoned equity offerings, Journal of Accounting and Economics 29, 339-371.

Stein, Jeremy C., 1989, Efficient capital markets, inefficient firms: A model of myopic corporate behavior, Quarterly Journal of Economics 104, 655-669.

Stein, Luke C. D., and Elizabeth C. Stone, 2014, The effect of uncertainty on investment, hiring, and R\&D: Causal evidence from equity options, Working paper, Arizona State University.

Subramanyam, K. R., 1996, The pricing of discretionary accruals, Journal of Accounting and Economics 22, 249-281.

Teoh, Siew Hong, Ivo Welch, and T. J. Wong, 1998a, Earnings management and the underperformance of seasoned equity offerings, Journal of Financial Economics 50, 63-99.

Teoh, Siew Hong, T. J. Wong, and Gita Rao, 1998b, Are accruals during initial public offerings opportunistic, Review of Accounting Studies 3, 175-208. 


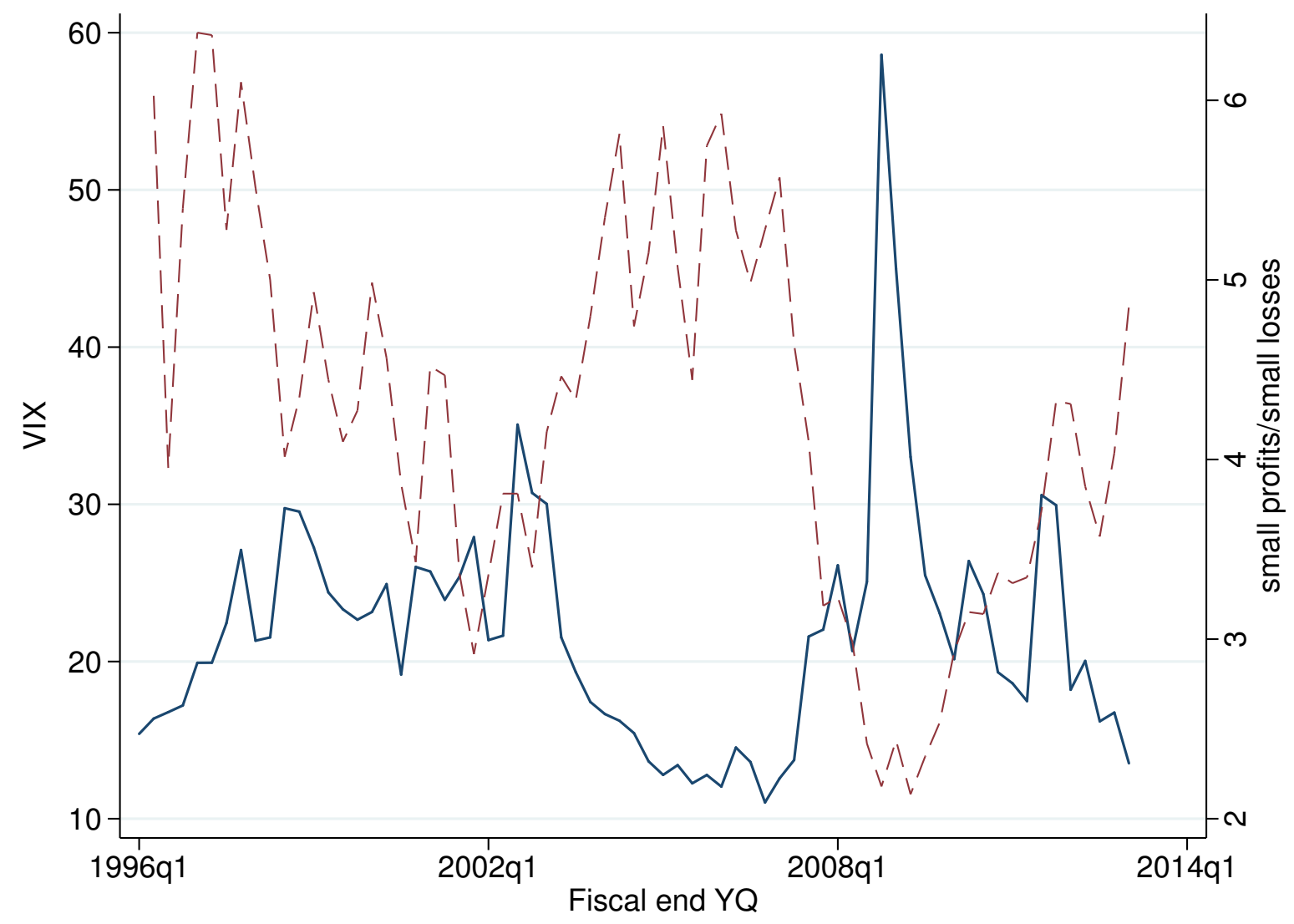

VIX $\quad-\quad--$ small profits/small losses

Figure 1. Aggregate Uncertainty and Earnings Management A firm-year observation is classified as having a small profit if positive after-tax net income falls within the range of 1 percent of lagged total assets; it is classified as a small loss if negative after-tax net income falls within that range. "Small profits/small losses" is the ratio (calculated for each calendar quarter) of the number of firms with small profits to the number with small losses. VIX signifies the average daily CBOE volatility index over the calendar quarter. 


\section{Table 1.}

\section{Main Variable Descriptions}

This table describes the variables used in our analysis and explains their construction. The principal data sources are Compustat for company financials and industry classifications, OptionMetrics for option-implied volatilities, CRSP for stock returns, I/B/E/S for analysts' forecasts, and Execucomp for executive compensation.

\begin{tabular}{|c|c|c|}
\hline Variable & Description & Calculation \\
\hline \multicolumn{3}{|c|}{ Outcome variables } \\
\hline$D A$ & Discretionary accruals & $\begin{array}{l}\text { Per modified-Jones model (as in Dechow et al., } \\
1995 \text { ), augmented with return-on-assets data } \\
\text { and estimated in the cross-section (follow- } \\
\text { ing Kothari et al., 2005): Residual values } \\
\text { from linear regressions of } T A \text { on } 1 /[\text { at }]_{t-1} \text {, } \\
\left.(\Delta[\mathrm{revt}]-\Delta[\mathrm{rect}]) /[\mathrm{at}]_{t-1} \text {, [ppent }\right] /[\mathrm{at}]_{t-1} \text {, and } \\
{[\text { oibdp }]_{t-1} /[\mathrm{at}]_{t-1} \text {, estimated separately for each }} \\
\text { period across all the Compustat firms in each } \\
\text { two-digit SIC code-based industry. All regressors } \\
\text { are winsorized at the } 0.5-99.5 \text { th percentiles of the } \\
\text { pooled sample. }\end{array}$ \\
\hline$T A$ & Total accruals & $([$ ibc $]-([$ oancf $]-[$ xidoc $])) /[\text { at }]_{t-1}$ \\
\hline$\Delta W C$ & Change in working capital & $([\mathrm{ca}]-[\mathrm{cl}])-\left([\mathrm{ca}]_{t-1}-[\mathrm{cl}]_{t-1}\right) /[\mathrm{at}]_{t-1}$ \\
\hline$r_{t-3}$ & $\begin{array}{l}\text { Earnings announcement re- } \\
\text { turn }\end{array}$ & $\begin{array}{l}\text { Cumulative stock return over a window beginning } \\
\text { three days before the earnings announcement and } \\
\text { ending the day after the announcement. }\end{array}$ \\
\hline
\end{tabular}

Main explanatory variables

impl vol Option-implied volatility

vol resid Implied volatility residual

surprise/price $\quad$ Earnings surprise normalized by stock price

surprise/assets $\quad$ Earnings surprise normalized by total assets
Implied volatility of 91-day, at-the-money-forward call options from OptionMetrics, winsorized at the 0.5-99.5th percentiles of the pooled sample.

Residual value from linear regression of $\mathrm{impl} \mathrm{vol}$ on $\ln ($ mktcap), $\ln ($ btm), debt/asset, inv interest cov, chairman, incentive, and quarter- and twodigit-SIC-level fixed effects.

Announced earnings per share minus median analyst forecast, divided by assets per share (calculated using total assets from most recently quarterly report and shares outstanding 21 days before earnings announcement).

Announced earnings per share minus median analyst forecast, divided by stock price 21 days before earnings announcement.

\section{Control variables}


Table 1.

Variable Descriptions (cont.)

\begin{tabular}{|c|c|c|}
\hline Variable & Description & Calculation \\
\hline $\ln (b t m)$ & Book-to-market ratio $(\log )$ & $\log \left([\mathrm{at}] /\left([\mathrm{at}]-\operatorname{ceq}+[\mathrm{csho}] \times\left[\right.\right.\right.$ prcc_f $\left.\left.\left._{-}\right]-[\mathrm{txdb}]\right)\right)$ \\
\hline debt/asset & Debt ratio & {$[\mathrm{dltt}] /[\mathrm{at}]$} \\
\hline inv interest $\operatorname{cov}_{t-1}$ & Inverse interest coverage & {$[\operatorname{xint}] /[$ oibdp] , capped at 2} \\
\hline chairman & $\mathrm{CEO}$ is also board chair & $\begin{array}{l}\text { Equals one if the CEO is reported in Execucomp } \\
\text { as as also being chairman of the board during the } \\
\text { fiscal period, and zero otherwise. }\end{array}$ \\
\hline incentive $_{t-1}$ & CEO equity incentive & $\begin{array}{lr}\text { Per Bergstresser and Philippon } & (2006) \text { : } \\
\text { onepct/(onepct+[salary] }+[\text { bonus }]), & \text { where } \\
\text { onepct }=0.01 \times[\text { prcc_f }] \times([\text { shrown_excl_opts }]+ \\
[\text { opt_unex_exer_num }]+[\text { opt_unex_unexer_num }])\end{array}$ \\
\hline${\text { adj } \text { incentive }_{t-1}}$ & $\begin{array}{l}\text { CEO equity incentive, ad- } \\
\text { justed for option delta }\end{array}$ & $\begin{array}{l}\text { Per Core and Guay (2002); implemented using } \\
\text { code from Coles et al. (2006a). }\end{array}$ \\
\hline tenure & CEO tenure & $\begin{array}{l}\text { Number of years since a different CEO was listed } \\
\text { in Execucomp (or, for first CEO in Execucomp, } \\
\text { numbers of years since current CEO was initially } \\
\text { listed). }\end{array}$ \\
\hline numest & $\begin{array}{l}\text { Number of analysts covering } \\
\text { firm }\end{array}$ & $\begin{array}{l}\text { Number of earnings forecasts from } \mathrm{I} / \mathrm{B} / \mathrm{E} / \mathrm{S} \text { on } \\
\text { the date immediately preceding the earnings an- } \\
\text { nouncement. }\end{array}$ \\
\hline ior & Institutional ownership & Calculated using code from Glushkov et al. (2009). \\
\hline
\end{tabular}




\section{Table 2.}

\section{Summary Statistics}

This table reports distributional summary statistics for our main variables of interest. Panel A reports summary statistics for the annual sample; Panel B reports summary statistics for the quarterly sample. For each variable in each dataset, we report the pooled mean, standard deviation $(\mathrm{sd})$, median $\left(p_{50}\right)$, first quartile $\left(p_{25}\right)$, third quartile $\left(p_{75}\right)$, skewness, and number of non-missing observations (count). The last row of each panel reports the total number of observations in the dataset.

\section{(a) Annual sample}

\begin{tabular}{|c|c|c|c|c|c|c|c|}
\hline & mean & $\mathrm{sd}$ & $p_{50}$ & $p_{25}$ & $p_{75}$ & skewness & count \\
\hline \multicolumn{8}{|c|}{ Discretionary accruals (\% of beginning-of-period assets) } \\
\hline CS ROA modified-Jones cash flow & -0.01 & 0.17 & -0.01 & -0.07 & 0.04 & -0.15 & 14,736 \\
\hline CS ROA Jones cash flow & -0.01 & 0.16 & -0.01 & -0.07 & 0.04 & -0.91 & 14,736 \\
\hline CS ROA modified-Jones balance sheet & 0.00 & 0.10 & 0.00 & -0.04 & 0.04 & -9.48 & 13,920 \\
\hline CS modified-Jones cash flow & 0.06 & 0.19 & 0.04 & -0.02 & 0.13 & -0.29 & 14,736 \\
\hline TS modified-Jones cash flow & -0.00 & 0.08 & -0.00 & -0.03 & 0.02 & 0.21 & 13,381 \\
\hline Ending 91-day implied volatility (\%) & 42.10 & 19.53 & 37.81 & 28.56 & 50.41 & 1.57 & 14,736 \\
\hline Market cap. (\$B) & 9.22 & 27.50 & 2.20 & 0.89 & 6.38 & 8.30 & 14,736 \\
\hline Sales $(\$ B)$ & 6.91 & 20.00 & 1.95 & 0.73 & 5.57 & 10.91 & 14,736 \\
\hline Book/market & 0.53 & 0.48 & 0.44 & 0.27 & 0.68 & 8.68 & 14,736 \\
\hline Debt/assets & 0.19 & 0.15 & 0.17 & 0.04 & 0.29 & 0.82 & 14,736 \\
\hline Inverse interest coverage & 0.20 & 0.40 & 0.09 & 0.03 & 0.18 & 3.84 & 14,736 \\
\hline CEO manipulation incentive (BP 2006) & 0.30 & 0.23 & 0.23 & 0.13 & 0.41 & 1.15 & 14,736 \\
\hline CEO manipulation incentive (CG 2002) & 0.26 & 0.23 & 0.19 & 0.10 & 0.36 & 1.34 & 14,342 \\
\hline $\mathrm{CEO}$ is board chair & 0.61 & 0.49 & 1.00 & 0.00 & 1.00 & -0.45 & 14,736 \\
\hline Observations & 14,736 & & & & & & \\
\hline
\end{tabular}

\section{(b) Quarterly sample}

\begin{tabular}{|c|c|c|c|c|c|c|c|}
\hline & mean & sd & $p_{50}$ & $p_{25}$ & $p_{75}$ & skewness & count \\
\hline \multicolumn{8}{|c|}{ Discretionary accruals (\% of beginning-of-period assets) } \\
\hline CS ROA modified-Jones cash flow & 0.00 & 0.05 & 0.00 & -0.01 & 0.02 & -9.39 & 54,271 \\
\hline CS ROA Jones cash flow & 0.00 & 0.05 & 0.00 & -0.02 & 0.02 & -9.39 & 54,271 \\
\hline CS ROA modified-Jones balance sheet & -0.00 & 0.04 & -0.00 & -0.02 & 0.02 & -3.83 & 50,263 \\
\hline CS modified-Jones cash flow & 0.02 & 0.05 & 0.02 & -0.00 & 0.04 & -7.72 & 54,271 \\
\hline TS modified-Jones cash flow & -0.00 & 0.04 & 0.00 & -0.01 & 0.01 & -5.17 & 54,217 \\
\hline Ending 91-day implied volatility (\%) & 41.97 & 18.95 & 37.90 & 28.78 & 50.38 & 1.53 & 54,271 \\
\hline Market cap. $(\$ B)$ & 8.74 & 26.73 & 2.04 & 0.82 & 5.87 & 8.47 & 54,271 \\
\hline Sales $(\$ B)$ & 1.70 & 4.99 & 0.47 & 0.18 & 1.35 & 10.83 & 54,271 \\
\hline Book/market & 0.55 & 0.56 & 0.44 & 0.28 & 0.69 & 14.43 & 54,271 \\
\hline Debt/assets & 0.20 & 0.16 & 0.18 & 0.06 & 0.30 & 1.03 & 54,271 \\
\hline Inverse interest coverage & 0.24 & 0.48 & 0.09 & 0.03 & 0.20 & 3.11 & 54,271 \\
\hline CEO manipulation incentive (BP 2006) & 0.29 & 0.22 & 0.23 & 0.13 & 0.40 & 1.18 & 54,271 \\
\hline CEO manipulation incentive (CG 2002) & 0.26 & 0.22 & 0.19 & 0.10 & 0.35 & 1.39 & 52,737 \\
\hline CEO is board chair & 0.60 & 0.49 & 1.00 & 0.00 & 1.00 & -0.39 & 54,271 \\
\hline (Earnings - Forecast) $/$ Price $_{t-21}(\%)$ & 0.01 & 1.26 & 0.05 & -0.03 & 0.18 & -11.20 & 54,271 \\
\hline (Earnings - Forecast) $/ \mathrm{TA}_{t-21}(\%)$ & 0.06 & 0.70 & 0.05 & -0.02 & 0.20 & -4.69 & 54,271 \\
\hline Announcement return $_{[t-3, t+1]}(\%)$ & 0.68 & 9.32 & 0.44 & -3.99 & 5.20 & 0.46 & 54,271 \\
\hline Announcement return $[t-20, t+1]$ & 1.53 & 15.18 & 1.33 & -6.11 & 8.70 & 1.09 & 54,271 \\
\hline Observations & 54,271 & & & & & & \\
\hline
\end{tabular}


Table 3.

Uncertainty and Discretionary Accruals

This table reports coefficients, standard errors, and statistical significance from OLS regressions of discretionary accruals on implied volatility and controls, using the annual sample described in Section 3. Discretionary accruals are calculated using the cross-sectional modified-Jones model with ROA and cash-flow data. Time fixed effects are quarterly; industry fixed effects are at the two-digit SIC level. Explanatory variables are calculated as described in Section 3. Standard errors two-way clustered by firm and period are reported in parentheses. Significance levels are indicated by ${ }^{*},{ }^{* *},{ }^{* * *}$ for $10 \%, 5 \%$, and $1 \%$ respectively.

\begin{tabular}{lccc}
\hline & $(1)$ & $(2)$ & $(3)$ \\
\hline impl vol & $-0.0707^{* * *}$ & $-0.0672^{* * *}$ & $-0.0439^{* *}$ \\
ln(mktcap) & $(0.0210)$ & $(0.0202)$ & $(0.0221)$ \\
& -0.0011 & -0.0012 & -0.0010 \\
ln(btm) & $(0.0018)$ & $(0.0019)$ & $(0.0064)$ \\
& $0.0199^{* * *}$ & $0.0190^{* * *}$ & -0.0020 \\
debt/asset & $(0.0035)$ & $(0.0033)$ & $(0.0049)$ \\
& $0.0451^{* * *}$ & $0.0441^{* * *}$ & 0.0025 \\
inv interest covt-1 & $(0.0149)$ & $(0.0137)$ & $(0.0159)$ \\
& $0.0312^{* * *}$ & $0.0280^{* * *}$ & $0.0449^{* * *}$ \\
incentive ${ }_{t-1}$ & $(0.0074)$ & $(0.0073)$ & $(0.0060)$ \\
& $-0.0347^{* * *}$ & $-0.0277^{* * *}$ & -0.0171 \\
chairman & $(0.0073)$ & $(0.0077)$ & $(0.0123)$ \\
& $0.0079^{* *}$ & $0.0076^{* *}$ & -0.0012 \\
Time fixed effects & $(0.0037)$ & $(0.0035)$ & $(0.0043)$ \\
Industry fixed effects & Yes & Yes & Yes \\
Firm fixed effects & Yes & No & No \\
Observations & No & No & 15,969 \\
Adjusted $R^{2}$ & 15,969 & 15,969 & -0.1364 \\
\hline
\end{tabular}


Table 4.

\section{Uncertainty and Accruals}

This table reports coefficients, standard errors, and statistical significance from OLS regressions of accruals measures on implied volatility and controls, using the annual sample described in Section 3. The dependent variable in column 1 is discretionary accruals, calculated using the cross-sectional modified-Jones model with ROA and cash-flow data; the dependent variable in column 2 is total accruals, calculated as the difference between net income and cash flow from operations; the dependent variable in column 3 is working-capital accruals, calculated as the change in working capital or the difference between the change in current assets and the change in current liabilities. All dependent variables are normalized by lagged total assets. Time fixed effects are quarterly; industry fixed effects are at the two-digit SIC level. Explanatory variables are calculated as described in Section 3. The last two rows report the pooled mean and standard deviation of each dependent variable. Standard errors two-way clustered by firm and period are reported in parentheses. Significance levels are indicated by ${ }^{*},{ }^{* *},{ }^{* * *}$ for $10 \%, 5 \%$, and $1 \%$ respectively.

\begin{tabular}{lccc}
\hline & $(1)$ & $(2)$ & $(3)$ \\
& $\mathrm{DA}$ & $\mathrm{TA}$ & $\Delta \mathrm{WC}$ \\
\hline impl vol & $-0.0716^{* * *}$ & $-0.0970^{* * *}$ & $-0.0103^{*}$ \\
& $(0.0222)$ & $(0.0111)$ & $(0.0060)$ \\
ln(mktcap) & -0.0008 & -0.0012 & $-0.0018^{* * *}$ \\
& $(0.0018)$ & $(0.0016)$ & $(0.0005)$ \\
ln(btm) & $0.0203^{* * *}$ & 0.0038 & $-0.0042^{* * *}$ \\
& $(0.0037)$ & $(0.0025)$ & $(0.0011)$ \\
debt/asset & $0.0474^{* * *}$ & -0.0049 & $0.0115^{* * *}$ \\
& $(0.0153)$ & $(0.0089)$ & $(0.0037)$ \\
inv interest cov $t-1$ & $0.0310^{* * *}$ & -0.0119 & $-0.0080^{* * *}$ \\
& $(0.0080)$ & $(0.0074)$ & $(0.0028)$ \\
incentive $t-1$ & $-0.0363^{* * *}$ & $-0.0270^{* * *}$ & 0.0029 \\
& $(0.0077)$ & $(0.0066)$ & $(0.0031)$ \\
chairman & $0.0076^{* *}$ & $0.0043^{* *}$ & -0.0006 \\
& $(0.0038)$ & $(0.0020)$ & $(0.0010)$ \\
\hline Time fixed effects & Yes & Yes & Yes \\
Industry fixed effects & Yes & Yes & Yes \\
Observations & 14,945 & 14,945 & 14,945 \\
Adjusted $R^{2}$ & 0.0431 & 0.0800 & 0.0564 \\
Mean(dep) & -.0247 & -.0616 & .0074 \\
Std(dep) & .1739 & .1084 & .058 \\
\hline
\end{tabular}


Table 5.

Uncertainty and Discretionary Accruals: Heterogeneous Effects by Executive Incentives

This table reports coefficients, standard errors, and statistical significance from OLS regressions of discretionary accruals on implied volatility and controls. Discretionary accruals are calculated using the cross-sectional modified-Jones model with ROA and cash-flow data. Estimation is on the annual sample described in Section 3 for which the control variables are available. Time fixed effects are quarterly; industry fixed effects are at the two-digit SIC level. Explanatory variables are calculated as described in Section 3. Standard errors two-way clustered by firm and period are reported in parentheses. Significance levels are indicated by ${ }^{*},{ }^{* *}$, ${ }^{* * *}$ for $10 \%, 5 \%$, and $1 \%$ respectively.

\begin{tabular}{|c|c|c|c|c|c|}
\hline & (1) & (2) & (3) & (4) & (5) \\
\hline impl vol & $\begin{array}{c}-0.0470^{* *} \\
(0.0210)\end{array}$ & $\begin{array}{c}-0.0525^{* *} \\
(0.0208)\end{array}$ & $\begin{array}{c}-0.1023^{* *} \\
(0.0453)\end{array}$ & $\begin{array}{c}-0.0886^{* *} \\
(0.0400)\end{array}$ & $\begin{array}{c}-0.0912^{\text {** }} \\
(0.0401)\end{array}$ \\
\hline incentive $_{t-1}$ & $\begin{array}{c}0.0459 \\
(0.0292)\end{array}$ & & $\begin{array}{c}-0.0303^{* * *} \\
(0.0072)\end{array}$ & $\begin{array}{c}0.0338 \\
(0.0279)\end{array}$ & \\
\hline${\text { impl vol } \times \text { incentive }_{t-1}}$ & $\begin{array}{c}-0.1891^{* * *} \\
(0.0698)\end{array}$ & & & $\begin{array}{c}-0.1477^{* *} \\
(0.0665)\end{array}$ & \\
\hline adj $_{\text {incentive }_{t-1}}$ & & $\begin{array}{c}0.0466 \\
(0.0301)\end{array}$ & & & $\begin{array}{c}0.0347 \\
(0.0279)\end{array}$ \\
\hline${\text { impl vol } \times a d j \text { incentive }_{t-1}}$ & & $\begin{array}{c}-0.1839^{* * *} \\
(0.0710)\end{array}$ & & & $\begin{array}{c}-0.1426^{* *} \\
(0.0660)\end{array}$ \\
\hline tenure & $\begin{array}{c}-0.0019^{* *} \\
(0.0009)\end{array}$ & $\begin{array}{c}-0.0019^{* *} \\
(0.0009)\end{array}$ & & $\begin{array}{c}-0.0017^{* *} \\
(0.0008)\end{array}$ & $\begin{array}{c}-0.0017^{* *} \\
(0.0008)\end{array}$ \\
\hline impl vol $\times$ tenure & $\begin{array}{c}0.0045^{* *} \\
(0.0022)\end{array}$ & $\begin{array}{c}0.0045^{* *} \\
(0.0023)\end{array}$ & & $\begin{array}{l}0.0041^{*} \\
(0.0021)\end{array}$ & $\begin{array}{l}0.0041^{*} \\
(0.0021)\end{array}$ \\
\hline numest & & & $\begin{array}{c}0.0002 \\
(0.0009)\end{array}$ & $\begin{array}{c}-0.0007 \\
(0.0008)\end{array}$ & $\begin{array}{l}-0.0006 \\
(0.0008)\end{array}$ \\
\hline impl vol $\times$ numest & & & $\begin{array}{c}-0.0048^{* *} \\
(0.0022)\end{array}$ & $\begin{array}{c}-0.0025 \\
(0.0021)\end{array}$ & $\begin{array}{l}-0.0027 \\
(0.0021)\end{array}$ \\
\hline$i o r$ & & & $\begin{array}{c}-0.0557^{*} \\
(0.0289)\end{array}$ & $\begin{array}{c}-0.0432^{*} \\
(0.0239)\end{array}$ & $\begin{array}{c}-0.0431^{*} \\
(0.0235)\end{array}$ \\
\hline impl vol $\times i o r$ & & & $\begin{array}{l}0.1261^{*} \\
(0.0675)\end{array}$ & $\begin{array}{l}0.0969^{*} \\
(0.0559)\end{array}$ & $\begin{array}{l}0.0968^{*} \\
(0.0552)\end{array}$ \\
\hline $\ln ($ mktcap) & $\begin{array}{l}-0.0004 \\
(0.0019)\end{array}$ & $\begin{array}{l}-0.0006 \\
(0.0018)\end{array}$ & $\begin{array}{c}0.0048^{* *} \\
(0.0023)\end{array}$ & $\begin{array}{c}0.0050^{* *} \\
(0.0024)\end{array}$ & $\begin{array}{c}0.0048^{* *} \\
(0.0024)\end{array}$ \\
\hline $\ln (b t m)$ & $\begin{array}{c}0.0187^{* * *} \\
(0.0036)\end{array}$ & $\begin{array}{c}0.0187^{* * *} \\
(0.0036)\end{array}$ & $\begin{array}{c}0.0191^{* * *} \\
(0.0037)\end{array}$ & $\begin{array}{c}0.0190^{* * *} \\
(0.0037)\end{array}$ & $\begin{array}{c}0.0190^{* * *} \\
(0.0037)\end{array}$ \\
\hline debt/asset & $\begin{array}{c}0.0411^{* * *} \\
(0.0150)\end{array}$ & $\begin{array}{c}0.0409^{* * *} \\
(0.0150)\end{array}$ & $\begin{array}{c}0.0427^{* * *} \\
(0.0149)\end{array}$ & $\begin{array}{c}0.0416^{* * *} \\
(0.0150)\end{array}$ & $\begin{array}{c}0.0415^{* * *} \\
(0.0150)\end{array}$ \\
\hline inv interest $\operatorname{cov}_{t-1}$ & $\begin{array}{c}0.0371^{* * *} \\
(0.0056)\end{array}$ & $\begin{array}{c}0.0373^{* * *} \\
(0.0056)\end{array}$ & $\begin{array}{c}0.0377^{* * *} \\
(0.0055)\end{array}$ & $\begin{array}{c}0.0375^{* * *} \\
(0.0053)\end{array}$ & $\begin{array}{c}0.0376^{* * *} \\
(0.0053)\end{array}$ \\
\hline chairman & $\begin{array}{c}0.0093^{* *} \\
(0.0040)\end{array}$ & $\begin{array}{c}0.0093^{* *} \\
(0.0040)\end{array}$ & $\begin{array}{c}0.0091^{* * *} \\
(0.0035)\end{array}$ & $\begin{array}{c}0.0088^{* *} \\
(0.0040)\end{array}$ & $\begin{array}{c}0.0088^{* *} \\
(0.0040)\end{array}$ \\
\hline Time fixed effects & Yes & Yes & Yes & Yes & Yes \\
\hline Industry fixed effects & Yes & Yes & Yes & Yes & Yes \\
\hline Observations & 14,726 & 14,726 & 14,726 & 14,726 & 14,726 \\
\hline Adjusted $R^{2}$ & 0.0534 & 0.0530 & 0.0543 & 0.0558 & 0.0556 \\
\hline
\end{tabular}


Table 6.

Uncertainty and Discretionary Accruals: Heterogeneous Effects by Sarbanes-Oxley Act

This table reports coefficients, standard errors, and statistical significance from OLS regressions of discretionary accruals on implied volatility and controls. Discretionary accruals are calculated using the cross-sectional modified-Jones model with ROA and cash-flow data. Estimation in columns 1-2 is on the pre-Sarbanes-Oxley subset of the annual sample described in Section 3; estimation in columns 3-4 is on the post-Sarbanes-Oxley subset. The post-Sarbanes-Oxley period is defined as observations with fiscal years ending in 2004 and later. Time fixed effects are quarterly; industry fixed effects are at the two-digit SIC level. Explanatory variables are calculated as described in Section 3. Standard errors two-way clustered by firm and period are reported in parentheses. Significance levels are indicated by ${ }^{*},{ }^{* *},{ }^{* * *}$ for $10 \%, 5 \%$, and $1 \%$ respectively.

\begin{tabular}{|c|c|c|c|c|}
\hline & $\begin{array}{c}(1) \\
\text { Pre-SOX }\end{array}$ & $\begin{array}{c}(2) \\
\text { Pre-SOX }\end{array}$ & $\begin{array}{c}(3) \\
\text { Post-SOX }\end{array}$ & $\begin{array}{c}(4) \\
\text { Post-SOX }\end{array}$ \\
\hline impl vol & $\begin{array}{c}-0.0948^{* * *} \\
(0.0320)\end{array}$ & $\begin{array}{l}-0.0641 \\
(0.0399)\end{array}$ & $\begin{array}{l}-0.0340^{*} \\
(0.0184)\end{array}$ & $\begin{array}{c}0.0159 \\
(0.0776)\end{array}$ \\
\hline incentive $_{t-1}$ & $\begin{array}{c}-0.0294^{* *} \\
(0.0129)\end{array}$ & $\begin{array}{c}0.0672^{*} \\
(0.0354)\end{array}$ & $\begin{array}{c}-0.0340^{* * *} \\
(0.0088)\end{array}$ & $\begin{array}{l}-0.0277 \\
(0.0246)\end{array}$ \\
\hline${\text { impl vol } \times \text { incentive }_{t-1}}$ & & $\begin{array}{c}-0.1886^{* *} \\
(0.0776)\end{array}$ & & $\begin{array}{c}0.0019 \\
(0.0567)\end{array}$ \\
\hline tenure & & $\begin{array}{c}-0.0022^{* *} \\
(0.0010)\end{array}$ & & $\begin{array}{l}-0.0003 \\
(0.0007)\end{array}$ \\
\hline impl vol $\times$ tenure & & $\begin{array}{l}0.0062^{* *} \\
(0.0025)\end{array}$ & & $\begin{array}{c}0.0002 \\
(0.0018)\end{array}$ \\
\hline numest & & $\begin{array}{c}0.0020 \\
(0.0016)\end{array}$ & & $\begin{array}{c}-0.0019^{* * *} \\
(0.0007)\end{array}$ \\
\hline impl vol $\times$ numest & & $\begin{array}{c}-0.0083^{* *} \\
(0.0042)\end{array}$ & & $\begin{array}{c}0.0001 \\
(0.0015)\end{array}$ \\
\hline ior & & $\begin{array}{l}-0.0545 \\
(0.0380)\end{array}$ & & $\begin{array}{c}0.0052 \\
(0.0320)\end{array}$ \\
\hline impl vol $\times$ ior & & $\begin{array}{c}0.1278 \\
(0.0856)\end{array}$ & & $\begin{array}{l}-0.0546 \\
(0.0807)\end{array}$ \\
\hline $\ln (m k t c a p)$ & $\begin{array}{l}-0.0055^{*} \\
(0.0030)\end{array}$ & $\begin{array}{c}0.0017 \\
(0.0042)\end{array}$ & $\begin{array}{c}0.0023 \\
(0.0017)\end{array}$ & $\begin{array}{c}0.0082^{* * *} \\
(0.0023)\end{array}$ \\
\hline $\ln (b t m)$ & $\begin{array}{c}0.0152^{* *} \\
(0.0072)\end{array}$ & $\begin{array}{c}0.0145^{* *} \\
(0.0070)\end{array}$ & $\begin{array}{c}0.0220^{* * *} \\
(0.0039)\end{array}$ & $\begin{array}{c}0.0210^{* * *} \\
(0.0039)\end{array}$ \\
\hline debt/asset & $\begin{array}{l}0.0508^{* *} \\
(0.0237)\end{array}$ & $\begin{array}{c}0.0533^{* *} \\
(0.0243)\end{array}$ & $\begin{array}{l}0.0319^{* *} \\
(0.0162)\end{array}$ & $\begin{array}{l}0.0280^{*} \\
(0.0159)\end{array}$ \\
\hline inv interest $\operatorname{cov}_{t-1}$ & $\begin{array}{c}0.0121 \\
(0.0148)\end{array}$ & $\begin{array}{c}0.0137 \\
(0.0138)\end{array}$ & $\begin{array}{c}0.0454^{* * *} \\
(0.0056)\end{array}$ & $\begin{array}{c}0.0453^{* * *} \\
(0.0053)\end{array}$ \\
\hline chairman & $\begin{array}{c}0.0073 \\
(0.0067)\end{array}$ & $\begin{array}{c}0.0084 \\
(0.0084)\end{array}$ & $\begin{array}{c}0.0089^{* *} \\
(0.0041)\end{array}$ & $\begin{array}{l}0.0090^{* *} \\
(0.0042)\end{array}$ \\
\hline Time fixed effects & Yes & Yes & Yes & Yes \\
\hline Industry fixed effects & Yes & Yes & Yes & Yes \\
\hline Observations & 6,020 & 5,564 & 9,949 & 9,659 \\
\hline Adjusted $R^{2}$ & 0.0530 & 0.0660 & 0.0485 & 0.0523 \\
\hline
\end{tabular}


Table 7.

Uncertainty and Discretionary Accruals:

\section{Alternative DA Measures and Sample Timing}

This table reports coefficients, standard errors, and statistical significance from OLS regressions of discretionary accruals on implied volatility and controls. Columns $1-5$ vary by the calculation of discretionary accruals: (column 1 ) cross-sectional modified-Jones model with ROA and cash-flow data; (2) cross-sectional Jones model with ROA and cash-flow data; (3) cross-sectional modified-Jones model with ROA and balance-sheet data; (4) cross-sectional modified-Jones model with cash-flow data; and (5) time-series modified-Jones model with cash-flow data. Estimation in columns 1-5 is on the subsample of the annual sample described in Section 3 for which all discretionary accrual measures are available. The dependent variable in columns 6 and 7 is discretionary accruals calculated using the cross-sectional modified-Jones model with ROA and cash-flow data. Column 6 restricts the annual sample to fiscal years ending on December 31. Column 7 replicates the baseline specification using quarterly data. Time fixed effects are quarterly; industry fixed effects are at the two-digit SIC level. Variables are calculated as described in Section 3. The last row reports the pooled standard deviation of each dependent variable. Standard errors two-way clustered by firm and period are reported in parentheses. Significance levels are indicated by ${ }^{*},{ }^{* *},{ }^{* * *}$ for $10 \%, 5 \%$, and $1 \%$ respectively.

\begin{tabular}{|c|c|c|c|c|c|c|c|}
\hline & $\begin{array}{c}(1) \\
\text { Baseline }\end{array}$ & $\begin{array}{c}(2) \\
\text { Jones }\end{array}$ & $\begin{array}{l}\text { (3) } \\
\text { BS }\end{array}$ & $\begin{array}{c}(4) \\
\text { No ROA }\end{array}$ & $\begin{array}{l}(5) \\
\text { TS }\end{array}$ & $\begin{array}{c}(6) \\
\text { Dec-end }\end{array}$ & $\begin{array}{l}(7) \\
\text { Qrt }\end{array}$ \\
\hline impl vol & $\begin{array}{c}-0.0930^{* * * *} \\
(0.0212)\end{array}$ & $\begin{array}{c}-0.0879^{* * * *} \\
(0.0212)\end{array}$ & $\begin{array}{c}-0.0366^{* * *} \\
(0.0101)\end{array}$ & $\begin{array}{c}-0.1161^{* * *} \\
(0.0275)\end{array}$ & $\begin{array}{c}-0.0397^{* * *} \\
(0.0095)\end{array}$ & $\begin{array}{c}-0.0651^{* *} \\
(0.0254)\end{array}$ & $\begin{array}{c}-0.0256^{* * *} \\
(0.0035)\end{array}$ \\
\hline $\ln (m k t c a p)$ & $\begin{array}{l}-0.0036 \\
(0.0025)\end{array}$ & $\begin{array}{l}-0.0030 \\
(0.0026)\end{array}$ & $\begin{array}{l}-0.0022 \\
(0.0014)\end{array}$ & $\begin{array}{c}-0.0067^{* *} \\
(0.0033)\end{array}$ & $\begin{array}{l}-0.0000 \\
(0.0010)\end{array}$ & $\begin{array}{c}0.0007 \\
(0.0021)\end{array}$ & $\begin{array}{l}-0.0006 \\
(0.0004)\end{array}$ \\
\hline $\ln (b t m)$ & $\begin{array}{c}0.0164^{* * *} \\
(0.0046)\end{array}$ & $\begin{array}{c}0.0175^{* * *} \\
(0.0045)\end{array}$ & $\begin{array}{c}0.0007 \\
(0.0033)\end{array}$ & $\begin{array}{l}-0.0021 \\
(0.0050)\end{array}$ & $\begin{array}{l}-0.0021 \\
(0.0015)\end{array}$ & $\begin{array}{c}0.0223^{* * *} \\
(0.0045)\end{array}$ & $\begin{array}{c}0.0038^{* * *} \\
(0.0006)\end{array}$ \\
\hline debt/asset & $\begin{array}{l}0.0566^{* *} \\
(0.0244)\end{array}$ & $\begin{array}{c}0.0525^{* *} \\
(0.0229)\end{array}$ & $\begin{array}{c}0.0354^{* * *} \\
(0.0099)\end{array}$ & $\begin{array}{l}0.0509^{*} \\
(0.0309)\end{array}$ & $\begin{array}{l}-0.0054 \\
(0.0067)\end{array}$ & $\begin{array}{c}0.0522^{* * *} \\
(0.0194)\end{array}$ & $\begin{array}{l}0.0059^{* *} \\
(0.0024)\end{array}$ \\
\hline inv interest $\operatorname{cov}_{t-1}$ & $\begin{array}{c}0.0236 \\
(0.0170)\end{array}$ & $\begin{array}{c}0.0227 \\
(0.0165)\end{array}$ & $\begin{array}{l}-0.0063 \\
(0.0094)\end{array}$ & $\begin{array}{c}-0.0504^{* *} \\
(0.0202)\end{array}$ & $\begin{array}{c}-0.0026 \\
(0.0047)\end{array}$ & $\begin{array}{c}0.0393^{* * *} \\
(0.0072)\end{array}$ & $\begin{array}{c}0.0104^{* * *} \\
(0.0015)\end{array}$ \\
\hline incentive $_{t-1}$ & $\begin{array}{c}-0.0424^{* * *} \\
(0.0132)\end{array}$ & $\begin{array}{c}-0.0440^{* * *} \\
(0.0130)\end{array}$ & $\begin{array}{c}-0.0119^{*} \\
(0.0067)\end{array}$ & $\begin{array}{l}-0.0227 \\
(0.0155)\end{array}$ & $\begin{array}{c}-0.0125^{* * *} \\
(0.0046)\end{array}$ & $\begin{array}{c}-0.0310^{* * *} \\
(0.0089)\end{array}$ & $\begin{array}{r}-0.0044^{* * *} \\
(0.0015)\end{array}$ \\
\hline chairman & $\begin{array}{c}0.0096^{* * *} \\
(0.0034)\end{array}$ & $\begin{array}{c}0.0098^{* * *} \\
(0.0031)\end{array}$ & $\begin{array}{c}0.0015 \\
(0.0018) \\
\end{array}$ & $\begin{array}{c}0.0116^{* * *} \\
(0.0040)\end{array}$ & $\begin{array}{c}0.0011 \\
(0.0019)\end{array}$ & $\begin{array}{c}0.0071 \\
(0.0050)\end{array}$ & $\begin{array}{c}0.0010 \\
(0.0006) \\
\end{array}$ \\
\hline Time fixed effects & Yes & Yes & Yes & Yes & Yes & Yes & Yes \\
\hline Industry fixed effects & Yes & Yes & Yes & Yes & Yes & Yes & Yes \\
\hline Observations & 13,918 & 13,918 & 13,918 & 13,918 & 13,918 & 10,770 & 53,729 \\
\hline Adjusted $R^{2}$ & 0.0328 & 0.0346 & 0.0260 & 0.1073 & 0.0238 & 0.0467 & 0.0386 \\
\hline $\operatorname{Std}(\mathrm{dep})$ & .2106 & .2036 & .1077 & .2522 & .0869 & .1727 & .0502 \\
\hline
\end{tabular}




\section{Table 8. \\ Uncertainty and Discretionary Accruals: Alternative Uncertainty Measures}

This table reports coefficients, standard errors, and statistical significance from OLS regressions of discretionary accruals on various measures of firm-level uncertainty and controls. Columns $1-5$ vary by the measure of uncertainty: (column 1) option-implied volatility, as in our baseline estimates; (2) the within-firm-year standard deviation of analysts' earnings forecasts, normalized by the share price 21 days before the earnings announcement; (3) the within-firm-year standard deviation of analysts' earnings forecasts, normalized by assets per share; (4) the standard deviation of the firm's realized daily stock returns over the year preceding this fiscal year; and (5) the standard deviation of the firm's realized daily stock returns over the fiscal year. Time fixed effects are quarterly; industry fixed effects are at the two-digit SIC level. Explanatory variables are calculated as described in Section 3. The last four rows report the pooled mean, standard deviation, and interquartile range of each uncertainty measure. Standard errors two-way clustered by firm and period are reported in parentheses. Significance levels are indicated by ${ }^{*},{ }^{* *},{ }^{* * *}$ for $10 \%, 5 \%$, and $1 \%$ respectively.

\begin{tabular}{lccccc}
\hline & $(1)$ & $(2)$ & $(3)$ & $(4)$ & $(5)$ \\
& impl vol & stdevest_pr21 & stdevest_ass21 & lag_avg_volr & avg_volr \\
\hline Uncertainty & $-0.0716^{* *}$ & $-2.6924^{* * *}$ & $-4.7650^{* * *}$ & $-0.0620^{* * *}$ & $-0.0735^{* * *}$ \\
& $(0.0291)$ & $(0.4310)$ & $(1.2458)$ & $(0.0186)$ & $(0.0263)$ \\
ln(mktcap) & -0.0004 & 0.0020 & 0.0013 & 0.0001 & -0.0003 \\
& $(0.0020)$ & $(0.0014)$ & $(0.0014)$ & $(0.0017)$ & $(0.0019)$ \\
ln(btm) & $0.0208^{* * *}$ & $0.0231^{* * *}$ & $0.0192^{* * *}$ & $0.0208^{* * *}$ & $0.0208^{* * *}$ \\
& $(0.0035)$ & $(0.0036)$ & $(0.0036)$ & $(0.0035)$ & $(0.0035)$ \\
debt/asset & $0.0505^{* * *}$ & $0.0562^{* * *}$ & $0.0436^{* * *}$ & $0.0472^{* * *}$ & $0.0484^{* * *}$ \\
& $(0.0146)$ & $(0.0146)$ & $(0.0150)$ & $(0.0145)$ & $(0.0146)$ \\
inv interest cov & & $0.0308^{* * *}$ & $0.0328^{* * *}$ & $0.0333^{* * *}$ & $0.0335^{* * *}$ \\
& $0.0328^{* * *}$ & $(0.0053)$ & $(0.0056)$ & $(0.0051)$ & $(0.0047)$ \\
incentive $t-1$ & $(0.0049)$ & $-0.0336^{* * *}$ & $-0.0314^{* * *}$ & $-0.0284^{* * *}$ & $-0.0275^{* * *}$ \\
& $-0.0278^{* * *}$ & $(0.0080)$ & $(0.0079)$ & $(0.0077)$ & $(0.0075)$ \\
chairman & $(0.0075)$ & $0.0072^{* *}$ & $0.0071^{* *}$ & $0.0071^{* *}$ \\
& $0.0070^{* *}$ & $0.0080^{* *}$ & $(0.0036)$ & $(0.0035)$ & $(0.0035)$ \\
\hline Time fixed effects & $(0.0034)$ & $(0.0036)$ & Yes & Yes & Yes \\
Industry fixed effects & Yes & Yes & Yes & Yes & Yes \\
Observations & 14,493 & 14,493 & 14,493 & 14,493 & 14,493 \\
Adjusted $R^{2}$ & 0.0509 & 0.0511 & 0.0513 & 0.0504 & 0.0512 \\
Mean(unc) & .406 & .0016 & .0013 & .4133 & .4041 \\
Std(unc) & .1856 & .0036 & .0021 & .1948 & .1905 \\
$p_{25}$ (unc) & .2771 & .0004 & .0004 & .2769 & .2696 \\
$p_{75}$ (unc) & .4866 & .0015 & .0015 & .5029 & .4938 \\
\hline
\end{tabular}


Table 9.

Uncertainty and the Earnings Response Coefficient

All columns report OLS estimates. The dependent variable in all regressions is stock market return over a window ending the day after the earnings announcement and beginning three days (or twenty days, in column 5) before the announcement. Estimation is on the quarterly sample described in Section 3. Time fixed effects are quarterly; industry fixed effects are at the two-digit SIC level. Variables are calculated as described in Section 3. Standard errors two-way clustered by firm and period are reported in parentheses. Significance levels are indicated by ${ }^{*},{ }^{* *},{ }^{* * *}$ for $10 \%, 5 \%$, and $1 \%$ respectively.

\begin{tabular}{|c|c|c|c|c|c|}
\hline & $\begin{array}{c}(1) \\
r_{t-3}\end{array}$ & $\begin{array}{c}(2) \\
r_{t-3}\end{array}$ & $\begin{array}{c}(3) \\
r_{t-3}\end{array}$ & $\begin{array}{c}(4) \\
r_{t-3}\end{array}$ & $\begin{array}{c}(5) \\
r_{t-20}\end{array}$ \\
\hline impl vol & $\begin{array}{c}0.0227^{* *} \\
(0.0096)\end{array}$ & $\begin{array}{c}0.0234^{* *} \\
(0.0092)\end{array}$ & $\begin{array}{c}0.0429^{* * *} \\
(0.0113)\end{array}$ & $\begin{array}{l}0.0202^{* *} \\
(0.0093)\end{array}$ & $\begin{array}{c}0.0654^{* *} \\
(0.0322)\end{array}$ \\
\hline surprise/price & $\begin{array}{c}2.8681^{* * *} \\
(0.2830)\end{array}$ & $\begin{array}{c}2.8688^{* * *} \\
(0.2796)\end{array}$ & $\begin{array}{c}2.8085^{* * *} \\
(0.3001)\end{array}$ & & $\begin{array}{c}4.4104^{* * *} \\
(0.4293)\end{array}$ \\
\hline surprise/price $\times$ impl vol & $\begin{array}{c}-1.9641^{* * *} \\
(0.2569)\end{array}$ & $\begin{array}{c}-1.9750^{* * *} \\
(0.2502)\end{array}$ & $\begin{array}{c}-1.8206^{* * *} \\
(0.2863)\end{array}$ & & $\begin{array}{c}-3.3094^{* * *} \\
(0.3895)\end{array}$ \\
\hline surprise/assets & & & & $\begin{array}{c}5.0793^{* * *} \\
(0.3700)\end{array}$ & \\
\hline surprise/assets $\times$ impl vol & & & & $\begin{array}{c}-3.9220^{* * *} \\
(0.4612)\end{array}$ & \\
\hline $\ln (m k t c a p)$ & $\begin{array}{c}0.0004 \\
(0.0005)\end{array}$ & $\begin{array}{l}-0.0001 \\
(0.0005)\end{array}$ & $\begin{array}{c}-0.0114^{* * *} \\
(0.0017)\end{array}$ & $\begin{array}{c}0.0005 \\
(0.0005)\end{array}$ & $\begin{array}{c}0.0016 \\
(0.0013)\end{array}$ \\
\hline $\ln (b t m)$ & $\begin{array}{c}0.0015 \\
(0.0009)\end{array}$ & $\begin{array}{c}0.0008 \\
(0.0009)\end{array}$ & $\begin{array}{c}0.0007 \\
(0.0014)\end{array}$ & $\begin{array}{c}0.0025^{* * *} \\
(0.0009)\end{array}$ & $\begin{array}{l}0.0060^{* *} \\
(0.0030)\end{array}$ \\
\hline debt/asset & $\begin{array}{c}0.0035 \\
(0.0029)\end{array}$ & $\begin{array}{c}0.0006 \\
(0.0034)\end{array}$ & $\begin{array}{l}-0.0043 \\
(0.0043)\end{array}$ & $\begin{array}{l}0.0058^{* *} \\
(0.0028)\end{array}$ & $\begin{array}{c}0.0094 \\
(0.0074)\end{array}$ \\
\hline inv interest $\operatorname{cov}_{t-1}$ & $\begin{array}{l}-0.0016 \\
(0.0016)\end{array}$ & $\begin{array}{l}-0.0021 \\
(0.0016)\end{array}$ & $\begin{array}{c}0.0033 \\
(0.0023)\end{array}$ & $\begin{array}{l}-0.0022 \\
(0.0016)\end{array}$ & $\begin{array}{l}-0.0005 \\
(0.0033)\end{array}$ \\
\hline incentive $_{t-1}$ & $\begin{array}{c}0.0007 \\
(0.0019)\end{array}$ & $\begin{array}{c}0.0030 \\
(0.0020)\end{array}$ & $\begin{array}{c}0.0016 \\
(0.0030)\end{array}$ & $\begin{array}{c}0.0004 \\
(0.0019)\end{array}$ & $\begin{array}{c}0.0013 \\
(0.0048)\end{array}$ \\
\hline chairman & $\begin{array}{c}0.0012 \\
(0.0009)\end{array}$ & $\begin{array}{c}0.0007 \\
(0.0009)\end{array}$ & $\begin{array}{c}0.0011 \\
(0.0013)\end{array}$ & $\begin{array}{c}0.0015^{*} \\
(0.0009)\end{array}$ & $\begin{array}{c}0.0020 \\
(0.0016)\end{array}$ \\
\hline Time fixed effects & Yes & Yes & Yes & Yes & Yes \\
\hline Industry fixed effects & Yes & No & No & Yes & Yes \\
\hline Firm fixed effects & No & No & Yes & No & No \\
\hline Observations & 53,729 & 53,729 & 53,715 & 53,729 & 53,729 \\
\hline Adjusted $R^{2}$ & 0.0650 & 0.0640 & -0.0023 & 0.0728 & 0.1612 \\
\hline
\end{tabular}


Table 10.

Uncertainty and Discretionary Accruals: Heterogeneous Effects at "High" vs. "Low" Uncertainty

This table reports coefficients, standard errors, and statistical significance from OLS regressions of discretionary accruals on implied volatility residuals, the positive part of volatility residuals, and controls, using the annual sample described in Section 3. Discretionary accruals are calculated using the cross-sectional modified-Jones model with ROA and cash-flow data. Volatility residuals are computed as the difference between implied volatility and the expected level of implied volatility, where the latter is the fitted value from a linear regression of implied volatility on the other listed control variables (including quarter and industry fixed effects). Time fixed effects are quarterly; industry fixed effects are at the two-digit SIC level. Explanatory variables are calculated as described in Section 3. Standard errors two-way clustered by firm and period are reported in parentheses, and are currently not corrected for the inclusion of generated regressors. Significance levels are indicated by ${ }^{*},{ }^{* *},{ }^{* * *}$ for $10 \%, 5 \%$, and $1 \%$ respectively.

\begin{tabular}{lccc}
\hline & $(1)$ & $(2)$ & $(3)$ \\
\hline vol resid & -0.0116 & 0.0036 & 0.0119 \\
max(0,vol resid) & $(0.0419)$ & $(0.0386)$ & $(0.0374)$ \\
& $-0.0923^{* *}$ & $-0.1160^{* * *}$ & $-0.0840^{*}$ \\
ln(mktcap) & $(0.0460)$ & $(0.0416)$ & $(0.0457)$ \\
& 0.0016 & 0.0015 & 0.0005 \\
ln(btm) & $(0.0014)$ & $(0.0016)$ & $(0.0060)$ \\
& $0.0208^{* * *}$ & $0.0203^{* * *}$ & -0.0015 \\
debt/asset & $(0.0037)$ & $(0.0036)$ & $(0.0049)$ \\
& $0.0480^{* * *}$ & $0.0498^{* * *}$ & 0.0038 \\
inv interest covt-1 & $(0.0148)$ & $(0.0139)$ & $(0.0158)$ \\
& $0.0253^{* * *}$ & $0.0227^{* * *}$ & $0.0419^{* * *}$ \\
incentive $t-1$ & $(0.0075)$ & $(0.0075)$ & $(0.0064)$ \\
& $-0.0388^{* * *}$ & $-0.0322^{* * *}$ & -0.0188 \\
chairman & $(0.0073)$ & $(0.0077)$ & $(0.0128)$ \\
& $0.0087^{* *}$ & $0.0087^{* *}$ & -0.0009 \\
Time fixed effects & $(0.0038)$ & $(0.0037)$ & $(0.0043)$ \\
Industry fixed effects & Yes & Yes & Yes \\
Firm fixed effects & Yes & No & Yes \\
Observations & No & 15,969 & -0.1361 \\
Adjusted $R^{2}$ & 0.0439 & 0.0301 & \\
\hline
\end{tabular}

